Report to the Subcommittee on Criminal J ustice, Drug Policy and Human Resources, Committee on Government Reform, House of Representatives

February 2000

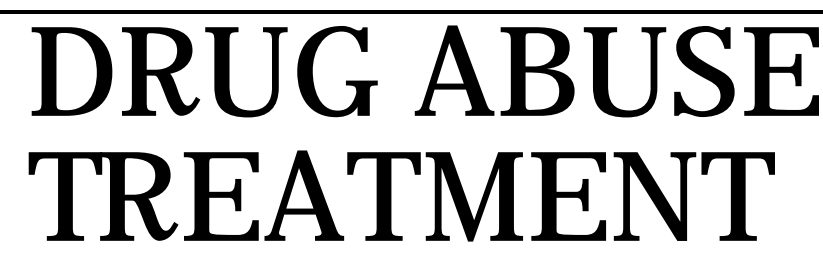

\title{
Efforts Under Way to Determine Effectiveness of State Programs
}
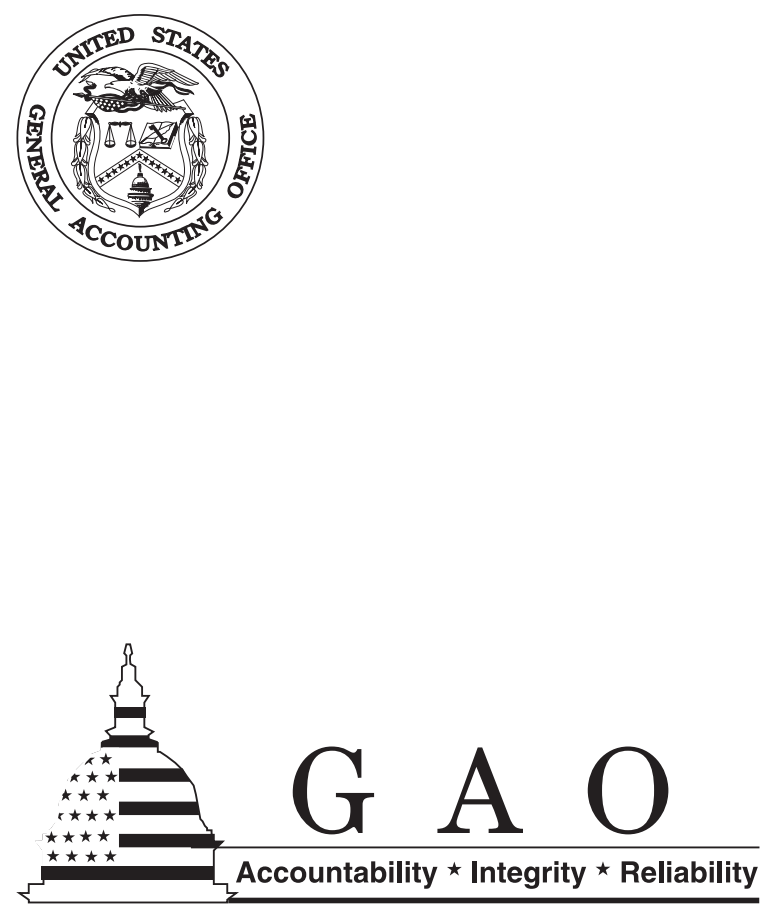



\section{Contents}

Appendix II: History and Administration of SAMHSA

Appendix III: KDA Grant Programs and Funding for Drug Abuse

Treatment

Appendix IV: State Program Assessments

Table 1: Characteristics of SAMHSA's Major Drug Abuse Treatment Studies

Table 2: States' Client Outcome Assessment Activities

Table 3: SAMHSA's Administrative Expenses, Fiscal Year 1999 Appropriation

Table 4: Selected SAMHSA Contracts for Technical Assistance and Program Evaluation, Fiscal Year 1999, by Agency and Program

Table 5: SAMHSA's Staffing Levels by Program, as of December 1999

\section{Figures}

Figure 1: Percentage of SAMHSA's Drug Abuse Treatment Expenditures for SAPT Block Grant and KDA Grant Programs, Fiscal Year 1996

Figure 2: Percentage of Surveyed State Agencies' Total Expenditures for Drug A buse Treatment Services by Funding Source, Fiscal Year 1996

Figure 3: Percent of SAPT Block Grant Expenditures for Methadone Services, Fiscal Year 1996 


\section{Contents}

\section{Abbreviations}

ADATSA Alcoholism and Drug Addiction Treatment and Support Act

HHS Department of Health and Human Services

KDA Knowledge Development and Application

NIDA National Institute on Drug Abuse

SAMHSA Substance Abuse and Mental Health Services Administration

SAPT Substance Abuse Prevention and Treatment

TASC Treatment Alternatives to Street Crime

TOPPS Treatment Outcomes and Performance Pilot Studies

TOPPS II Treatment Outcomes and Performance Pilot Studies Enhancement 
February 15,2000

The Honorable J ohn L. Mica

Chairman

The Honorable Patsy Mink

Ranking Minority Member

Subcommittee on Criminal J ustice, Drug Policy

and Human Resources

Committee on Government Reform

House of Representatives

Drug abuse continues to be a major national problem and concern. National survey data show that in 1998, 13.6 million Americans reported that they had used an illicit drug in the past month. The cost of drug abuse to society- which includes costs for health care, drug addiction prevention and treatment, drug-related crime prevention, and lost resources resulting from reduced worker productivity or death - is estimated at $\$ 67$ billion annually. For treatment-related programs, the federal government spent more than $\$ 3.2$ billion in fiscal year $1998 .{ }^{1}$ To better understand how federal funds are used, you asked us to describe efforts by the Substance Abuse and Mental Health Services Administration (SAMHSA) and states to provide effective drug abuse treatment programs. Specifically, you asked us to describe (1) activities supported by SAMHSA's Substance Abuse Prevention and Treatment (SAPT) block grant and Knowledge Development and Application (KDA) grant funds for drug abuse treatment; (2) SAMHSA and state mechanisms for monitoring fund use; and (3) SAMHSA and state efforts to determine the effectiveness of drug abuse treatment supported with SAPT block grant funds.

Our work on SAPT program activities included a survey of the 16 states that received at least $\$ 25$ million for their fiscal year 1996 SAPT block grant award: California, Florida, Georgia, Illinois, Indiana, Maryland, Massachusetts, Michigan, New Jersey, New York, North Carolina, Ohio, Pennsylvania, Texas, Virginia, and Washington. We interviewed selected respondents on their use of these funds for residential and outpatient drug

${ }^{1}$ The $\$ 3.2$ billion represents funding from eight federal agencies: the F ederal J udiciary; the Departments of Health and Human Services, Veterans Affairs, Defense, Education, Housing and Urban Development, and J ustice; and the Office of National Drug Control Policy. 
abuse treatment services, including detoxification and methadone maintenance. We asked states to exclude their use of SAPT block grant funds for activities other than drug abuse treatment, such as alcohol treatment and prevention from their survey responses. We also interviewed officials in SAMHSA's Center for Substance Abuse Treatment, Office of Program Services, and Office of Applied Studies, and reviewed documents they provided on SAPT and KDA activities funded with drug abuse treatment dollars.

Although the 16 states we surveyed represented about 60 percent of SAPT block grant drug abuse treatment expenditures for services, the results of our survey are not necessarily generalizable to all states. Our review focused on expenditures of fiscal year 1996 drug abuse treatment funds because, at the time of our review, it was the latest year for which complete expenditure data from SAMHSA and the states on the SAPT block grant were available. Also, some survey states provided estimates of drug abuse treatment expenditures because they could not separate drug from alcohol abuse treatment services or could not isolate SAPT block grant expenditures from their total drug abuse treatment expenditures. (See app. I for a detailed description of our scope and methodology.) We did our work from J anuary 1999 to J anuary 2000 in accordance with generally accepted government auditing standards. abuse treatment programs, and although there is currently little information on their effectiveness, SAMHSA and some states have efforts under way to measure these programs' outcomes. About $\$ 581$ million in SAMHSA's fiscal year 1996 grant funds was spent on drug abuse treatment activities. Of these funds, more than 80 percent ( $\$ 478$ million) was spent by all states for treatment services funded through the SAPT block grant program. The 16 states we surveyed reported that SAPT funds supported both residential and outpatient drug abuse treatment services, including detoxification and methadone maintenance. For half of the states in our survey, outpatient drug abuse treatment services accounted for 57 to 85 percent of their block grant expenditures; the average of the remaining states' expenditures for outpatient services was 31 percent. All of the states we surveyed reported providing methadone treatment services almost exclusively on an outpatient basis. SAMHSA spent another $\$ 25$ million of the SAPT block grant for technical assistance and evaluation activities related to drug abuse treatment. The remaining $\$ 78$ million of SAMHSA's fiscal year 1996 grants were KDA funds provided to community-based 
organizations, universities, and state and local government agencies to develop and disseminate information on promising drug abuse treatment practices.

To monitor grantees' use of SAPT and KDA program funds, SAMHSA uses on-site reviews, reviews of independent financial audit reports, and application reviews. These mechanisms are primarily used to monitor grantees' compliance with program requirements, identify grantees' technical assistance needs, and provide grantees guidance for improving program operations. The current accountability system for the SAPT block grant is mostly based on a review of state expenditures. As a result, SAMHSA primarily monitors states' compliance with certain statutory requirements for use of funds, such as those that stipulate that a certain percentage be used to treat special populations. The states we surveyed also reported that they monitor SAPT block grant funds provided to third parties, including counties and providers, using mechanisms similar to SAMHSA's. They used the results of their monitoring efforts, in part, to make drug abuse treatment funding allocation decisions and determine technical assistance needs.

Several state and SAMHSA efforts are under way to determine the effectiveness of drug abuse treatment programs using client outcome measures, such as drug use, employment, criminal activity, and living arrangement. Nine of the 16 states that we surveyed have conducted such assessments, but the outcomes measured, populations assessed, methodologies used, and availability of results vary from state to state. SAMHSA officials believe that collecting uniform state-level client outcome and other performance data is critical to determining the effectiveness of state programs supported with SAPT block grant funds. Consequently, SAMHSA is funding a pilot effort to help 19 states develop and uniformly report on a core set of client outcomes. SAMHSA has also asked all states to voluntarily report client outcome data in their fiscal year 2000 block grant application. How ever, this effort is not likely to result in uniform state data because some of the states we surveyed reported that they would not be able to submit all of the requested data because they are not currently collecting it. 
pharmacotherapy, psychosocial/behavioral therapy, or both.

Pharmacotherapy relies on medications to interfere with the euphoric effects or manage the withdrawal symptoms and cravings experienced with illicit drug use. One widely used medication is methadone, an opioid agonist that blocks or interferes with the euphoria of heroin, morphine, and other opiate drugs and suppresses withdrawal symptoms and cravings between treatment doses. Psychosocial/behavioral therapy may include skills training and a variety of counseling approaches, including individual, family, or group counseling.

SAMHSA, an agency within the Department of Health and Human Services (HHS), has primary responsibility for supporting substance abuse treatment and prevention activities. (See app. II for a detailed description of SAMHSA's role, program staffing, and budget authority.) SAMHSA awards 95 percent of SAPT block grant funds to states and U.S. territories to fund local drug and alcohol abuse treatment and prevention programs and retains 5 percent for program evaluation and other administrative purposes. State awards are determined by a statutory formula based on several factors, including a state's personal income data, taxable resources, population estimates, and service costs. To obtain a block grant, a state must submit to SAMHSA for review and approval an annual application that includes a discussion of how the state intends to comply with the various block grant requirements.

States have broad discretion in how they distribute SAPT block grant funds to cities, counties, and service providers; the services they support; and the specific amount allocated to drug abuse treatment. SAPT block grant legislation specifies that at least 35 percent of the state block grant award be used for alcohol prevention and treatment activities and 35 percent be used for other drug abuse prevention and treatment activities. The remaining 30 percent can be used at the state's discretion for drug programs, alcohol programs, or both. Further, states are required to satisfy certain statutory set-aside requirements for allocating a portion of SAPT funds for special populations, such as pregnant and postpartum women and their children, and, in certain states, to provide early intervention services for those with HIV.

SAPT block grant legislation requires that 5 percent of the SAPT block grant be set aside at the federal level to support data collection, program evaluation, and technical assistance to the states. For example, this setaside funds four major surveys required by the Public Health Service Act: the National Household Survey on Drug Abuse, the Drug Abuse Warning 
Network, the Drug Abuse Services Information System, and the Alcohol and Drug Services Survey. These surveys are intended to provide information for formulating substance abuse policy and evaluating the performance of programs and activities supported with federal funds. Another study supported by the set-aside, the Services Research Outcome Study, is a national study that used client outcome measures to assess the effectiveness of drug abuse treatment.

The KDA program is SAMHSA's discretionary grant program that replaced the demonstration grant program in $1996 .{ }^{2}$ KDA program grants are designed to bridge the gap between knowledge and practice in order to transfer research findings to community practitioners and to provide new, more efficient ways to deliver services. Funds are provided to communitybased organizations, universities, and state and local government agencies for developing and promoting effective approaches to providing substance abuse treatment services as well as prevention and mental health services. The KDA program is also used to expand the availability of treatment services for specific locations and populations. KDA topics are determined based on assessments of research and needs in the field as well as input from drug abuse experts, providers, clinicians, and congressional offices. Grant proposals are screened, peer reviewed, and scored based on criteria that include the proposed methodology for addressing the KDA topic as well as the populations to be researched.

2SAMHSA's demonstration grant program was part of an effort to establish a system for developing, documenting, and disseminating successful approaches to prevent and treat substance abuse and mental illness. The KDA effort emerged from the demonstration grant program and, according to SAMHSA officials, uses more rigorous evaluation methods and focuses on developing findings that can be adopted in other treatment settings. 
The Government Performance and Results Act of 1993 (Results Act)enacted to increase federal program effectiveness and accountabilityrequires federal agencies to set program goals, measure performance, and report to the Congress on their accomplishments. SAMHSA develops performance goals for the SAPT block grant program as part of HHS' Results Act reporting. In 1995, HHS requested that the National Academy of Science's National Research Council convene an expert panel to examine and report on the technical issues involved in establishing performance measures in 10 program areas, including substance abuse treatment. The conclusions and recommendations from the report that resulted from this effort were used to support SAMHSA's current efforts to develop and collect state-level client outcome data. ${ }^{3}$

Drug Abuse Treatment Funds Support Services, Technical Assistance, and Evaluation
Fiscal year 1996 expenditures for drug abuse treatment activities funded by SAMHSA's SAPT block grant and KDA grant programs totaled \$581 million. About 82 percent of these expenditures supported outpatient and residential treatment services and methadone maintenance- the pharmacotherapy treatment most widely used for heroin and other opiate addictions. For the 16 states we surveyed, outpatient services accounted for almost half of their SAPT block grant drug abuse treatment expenditures. The remaining 18 percent of SAMHSA's grant funds for drug abuse treatment activities supported technical assistance and program evaluation funded by the SAPT block grant set-aside and the development and dissemination of information on promising treatment practices funded by the KDA grant program.

\section{SAPT Block Grant Accounted for Most of SAMHSA's Grant F unds Used for Drug Abuse Treatment}

In fiscal year 1996, about \$581 million in SAMHSA grant funds supported activities related to drug abuse treatment. State SAPT block grant expenditures accounted for about $\$ 478$ million, ${ }^{4}$ and the SAPT set-aside for technical assistance contracts and program evaluation efforts accounted for another $\$ 25$ million. The remaining $\$ 78$ million supported KDA grants for programs designed to develop promising treatment practices that can

\footnotetext{
${ }^{3}$ Assessment of Performance Measures for Public Health, Substance Abuse, and Mental Health, National Research Council, 1997.

${ }^{4}$ In addition to state expenditures for drug abuse treatment, states spent about $\$ 681$ million in SAPT block grant awards to support alcohol treatment, primary prevention, tuberculosis and HIV early intervention services, and administration.
} 

and disseminate information to the public and treatment community. (See fig. 1.)

Figure 1: Percentage of SAMHSA's Drug Abuse Treatment Expenditures for SAPT Block Grant and KDA Grant Programs, Fiscal Year 1996

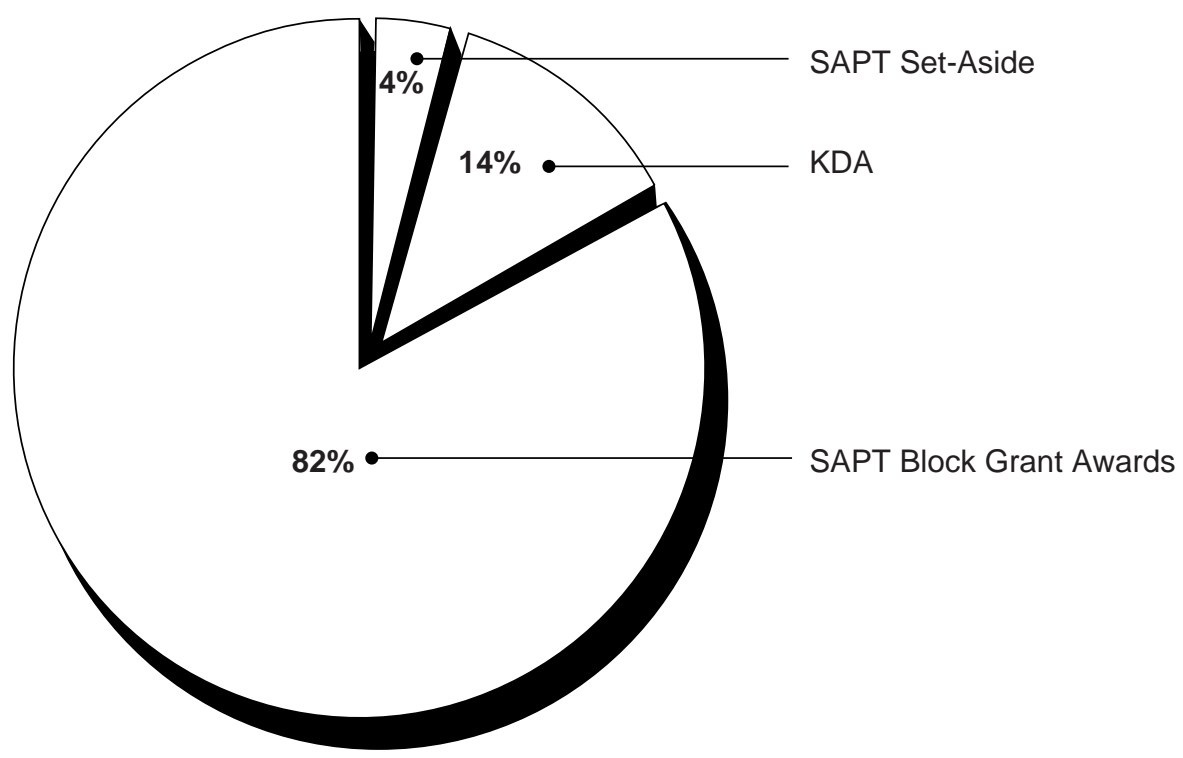

In addition to block grant funds, states use other revenue sources to fund drug abuse treatment services, including state funds; other federal funds, such as Medicaid; and county funds and insurance payments. The proportion of total drug abuse treatment expenditures accounted for by SAPT block grant expenditures varied considerably among the states we surveyed (see fig. 2). For example, New York reported that SAPT block grant expenditures accounted for 18 percent of its total reported funds for drug abuse treatment compared with 76 percent reported by Indiana. Expenditure data reported by the states we surveyed result from drug abuse treatment funds that flow through the state agency responsible for administering the SAPT block grant. In some states, other agencies also fund drug abuse treatment. 
Figure 2: Percentage of Surveyed State Agencies' Total Expenditures for Drug Abuse Treatment Services by Funding Source, Fiscal Year 1996

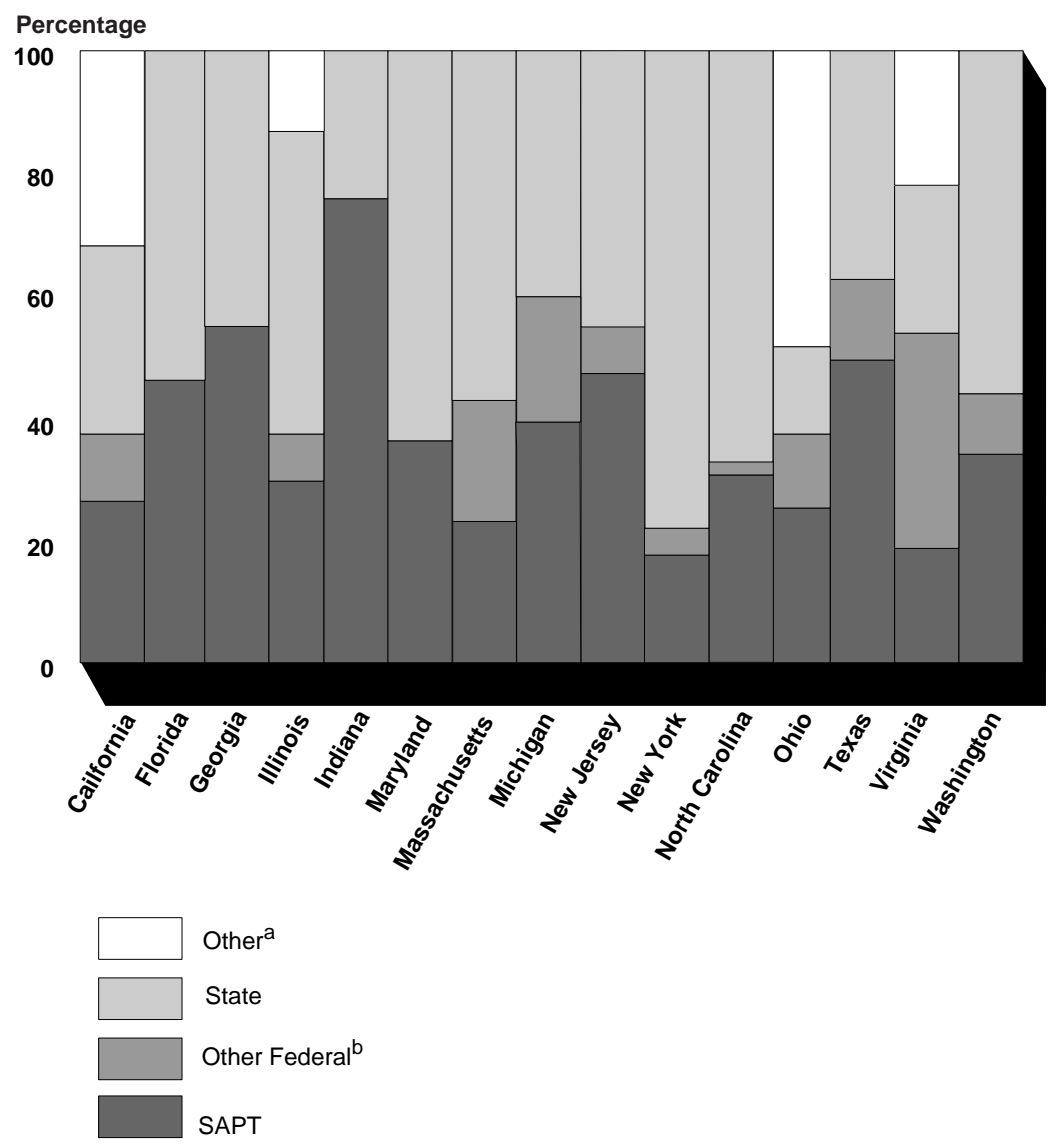

Note: Florida, Illinois, Massachusetts, Michigan, North Carolina, Ohio, and Washington provided estimates of fiscal year 1996 drug abuse treatment expenditures by funding source. Pennsylvania is not included. Pennsylvania officials reported that drug abuse treatment expenditure information was not available for other federal, state, and other funding sources because, aside from the SAPT block grant, they do not track drug abuse treatment expenditures separately from alcohol treatment expenditures. The officials stated that estimates could be constructed using client information but that such estimates would not take into consideration potential variations in the cost of treating alcohol versus drug abuse.

a"Other" refers to funds other than state and federal funds, such as county funds and insurance payments.

b"Other federal" refers to federal funds other than SAPT block grant funds, such as Medicaid. 
Most States' SAPT Block Grant Funds for Drug Abuse Treatment Were Used for Outpatient Services
The 16 states we surveyed reported spending a total of about $\$ 300$ million of SAPT block grant funding on drug abuse treatment, which included, for example, detoxification and methadone maintenance in residential and outpatient settings. The largest portion of reported drug abuse treatment expenditures was for services in outpatient settings, which can vary from psychotherapy to group counseling and may include pharmacological treatment. Of the 16 states surveyed, 14 reported spending SAPT block grant funds on outpatient services: 8 states spent between 57 and 85 percent of funds on these services; the average of the 6 remaining states' expenditures for outpatient services was 31 percent. $^{5}$

All of the states we surveyed reported that SAPT block grant expenditures supported methadone treatment, which is the pharmacotherapy treatment most widely used for heroin addiction. Methadone maintenance generally requires clients to receive daily methadone dosages that can continue for several years and, in some cases, may last a lifetime. The states we surveyed reported providing methadone maintenance almost exclusively as an outpatient service. Of the 16 states surveyed, 14 reported spending a total of $\$ 42.7$ million of fiscal year 1996 SAPT block grant funds for methadone provided on an outpatient basis. ${ }^{6}$ SAPT block grant expenditures for methadone services ranged from 2 percent to about 50 percent of total block grant expenditures for drug abuse treatment (see fig. 3). This range in expenditures is an example of the flexibility states have in determining the services supported by SAPT block grant funds.
${ }^{5}$ The remaining two states did not report the portion of SAPT block grant funds spent on outpatient services.

${ }^{6}$ Michigan and North Carolina state officials reported that they could not provide information on methadone expenditures supported with SAPT block grant funds because methadone expenditures could not be disaggregated from other SAPT block grant expenditures for drug abuse treatment. 
Figure 3: Percent of SAPT Block Grant Expenditures for Methadone Services, Fiscal Year 1996

Percentage

50

40

30

20

10

0

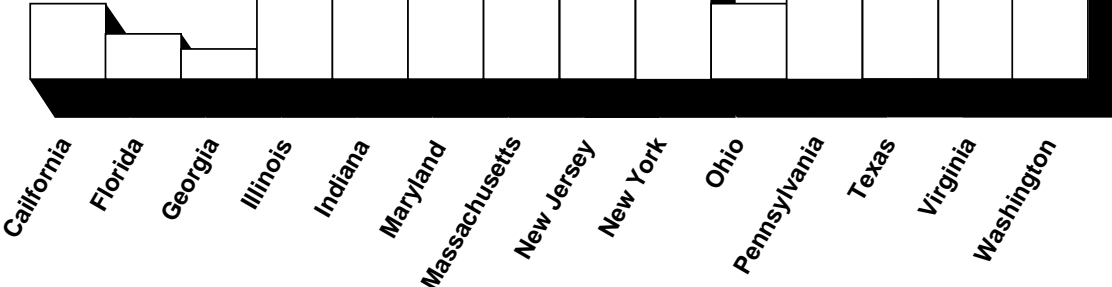

Note: Illinois, New Jersey, Ohio, Pennsylvania, and Washington officials provided estimates of SAPT block grant expenditures for methadone services. Michigan and North Carolina did not provide data on these expenditures and were, therefore, not included. 
SAMHSA U ses SAPT Block Grant Set-Aside F unds to Support Technical Assistance
SAMHSA spent about \$25 million of the fiscal year 1996 SAPT block grant set-aside to provide technical assistance to states and for program evaluation activities related to drug abuse treatment. About 93 percent of these funds supported technical assistance activities, including $\$ 11$ million for technical assistance contracts and $\$ 12$ million for the State Treatment Needs Assessment Program; the remaining $\$ 2$ million supported program evaluation activities. At the request of states, SAMHSA uses technical assistance contracts to provide a wide range of activities, which include conducting training seminars, redesigning treatment policies and procedures, and assisting states in establishing cost-effective treatment models. SAMHSA developed the State Treatment Needs Assessment Program to help states better allocate treatment funds, enhance and sustain states' capabilities to assess treatment need, and improve states' reporting of their needs assessments in block grant applications. In September 1998, we reported that some state officials have found this program useful for targeting resources and enhancing service delivery. However, states have been slow in developing the capacity to assess need and to report results developed from the program in their SAPT block grant applications. $^{7}$
SAMHSA's KDA Grant Funds Identify and Promote Promising Treatment Practices
SAMHSA awarded $\$ 78$ million of fiscal year 1996 KDA discretionary grants to determine the effectiveness of selected treatment practices, expand the availability of treatment services for specific locations and populations, and promote the adoption of best practices and treatment techniques. KDA funds supported grants and cooperative agreements to 111 communitybased organizations, universities, and state and local government agencies in support of 13 specific drug abuse treatment programs in fiscal year 1996. In fiscal year 1998, KDA treatment expenditures increased to about $\$ 98$ million supporting 27 specific programs. ${ }^{8}$ (See app. III for a description of KDA programs funded in fiscal years 1996 and 1998.) KDA programs funded in these years include the following:

${ }^{7}$ Drug Abuse Treatment: Data Limitations Affect the Accuracy of National and State Estimates of Need (GAO/HEHS-98-229, Sept. 15, 1998).

${ }^{8} \mathrm{~F}$ inal results have not been reported on the effectiveness of selected treatment practices for specific KDA programs. 
- Wraparound Services to evaluate the effect that services such as child care, vocational training, and transportation have on the effectiveness of treatment services.

- Marijuana-Adults to evaluate the effectiveness of brief treatment interventions for marijuana dependence and relapse and determine whether these interventions are effective for individuals from differing socioeconomic, racial, and ethnic backgrounds.

- Pregnant and Postpartum Women to expand the availability of comprehensive treatment services for pregnant and postpartum women and their children.

- Rural Remote and Culturally Distinct Populations to provide treatment services for harder-to-reach populations and serve as a model program for Alaskan Natives, American Indians, and Native Hawaiians.

- Addiction Technology Transfer Centers to promote the transfer of promising treatment practices to drug abuse treatment providers.

To help improve the overall quality of substance abuse treatment and facilitate the adoption of practices that have been identified as effective treatment approaches, SAMHSA develops and publishes best practice guidelines. For example, SAMHSA developed treatment improvement protocols by bringing together clinicians, researchers, policymakers, and other federal and nonfederal experts to identify and reach consensus on promising treatment practices. The published protocols recommend strategies to enhance treatment services for individuals with coexisting mental health and substance abuse disorders; offer guidelines for the design and delivery of effective treatment services for adolescents; and offer guidelines for planning, providing, and evaluating detoxification services. SAMHSA also developed a protocol to assist state agencies in developing, implementing, and managing outcome monitoring systems for increasing accountability for treatment expenditures. The treatment improvement protocols are being evaluated by an independent contractor to determine their effectiveness. SAMHSA also publishes technical assistance publications, which compile materials gathered from various federal, state, programmatic, and clinical sources that provide guidance and information related to providing substance abuse treatment services.

SAMHSA coordinates its KDA efforts with the National Institutes of Health's National Institute on Drug Abuse (NIDA). Coordination activities include periodic meetings to ensure that NIDA research is considered in the development, application, and dissemination of KDA information on promising treatment practices. For example, the KDA programs related to adolescent treatment, methamphetamine abuse treatment, and 
interventions for marijuana abusers reflect clinical research originally funded by NIDA. These KDA programs test NIDA research to establish the effectiveness of treatment approaches and to identify and address barriers to the use of these approaches in different communities and with different populations. SAMHSA and NIDA also use interagency agreements to draw on each other's expertise and avoid duplication of effort. SAMHSA also routinely involves NIDA in selecting treatment improvement protocol topics to ensure that they do not duplicate activities funded by the National Institutes of Health and in reviewing the protocols before publication. Further, NIDA grantees participate on the consensus panels for the development of the treatment improvement protocols. SAMHSA officials said that they also coordinate with the National Institute on Alcohol Abuse and Alcoholism.

Several Mechanisms Are Used to Monitor SAPT Block Grant and KDA Grant Funds
SAMHSA uses on-site reviews, reviews of independent financial audit reports required by the Single Audit Act, and reviews of grant applications to monitor grantees' use of SAPT and KDA funds and their compliance with program requirements. The accountability system for SAPT block grant funds is primarily based on whether states spend SAPT funds as required by federal law. SAMHSA is statutorily mandated to use on-site reviews to ensure states comply with requirements for the use of funds, such as the "maintenance of effort" requirement, which stipulates that states must maintain a certain level of expenditures for drug abuse treatment. On-site reviews are also used to identify grantees' technical assistance needs and provide guidance and recommendations to grantees for improving program operations. States, which distribute SAPT block grant funds to third parties such as treatment providers, reported using a variety of mechanisms to monitor third-party use of SAPT block grant funds. These mechanisms include site visits, management information systems, cost and activity reports, fiscal audits, and independent peer reviews. Most of the surveyed states reported using the results of their monitoring activities to, in part, make funding allocations and determine technical assistance needs.
On-Site Reviews Used to Monitor Compliance and Identify Technical Assistance Needs
SAMHSA is statutorily required to conduct on-site reviews to monitor SAPT block grant expenditures in at least 10 states each fiscal year. SAMHSA contracts with an independent firm to conduct these on-site reviews at the state and local levels. These reviews examine grantees' fiscal monitoring of providers and compliance with SAPT block grant requirements that include maintaining a certain level of state expenditures for drug abuse treatment and spending a certain percentage of funds on services for pregnant and 
postpartum women and their children. In practice, each state receives a review on average once every 3 years, and the review is generally conducted by one or two persons over a 5-day period. Although the on-site review process includes collecting and reviewing documents describing agency and program operations, the primary component of the review is a series of interviews conducted with state and local program officials. After the on-site review, the contractor works with SAMHSA program staff and state officials to develop a report detailing the contractor's findings. SAMHSA does not currently collect corrective action plans from states or track states' responses to identified deficiencies to determine if deficiencies are resolved. SAMHSA officials said that corrective action plans and SAMHSA's monitoring of them are needed, but the agency has not yet decided how it will address this issue.

SAMHSA uses the results from the on-site reviews to identify states' technical assistance needs. For example, Ohio's 1999 review resulted in two technical assistance recommendations: (1) develop utilization review guidelines for monitoring grantees and (2) provide training on SAPT block grant set-aside requirements for funding tuberculosis and HIV services. States must initiate requests for technical assistance, which SAMHSA provides through contractors that include experts who specialize in treatment service issues. In addition to on-site compliance reviews, SAMHSA project officers periodically conduct site visits to states and local treatment providers, identifying technical assistance needs and providing program guidance.

For the KDA program, SAMHSA officials told us that project officers monitor grantees through site visits as well as conference calls and other regular meetings. The goal of monitoring KDA programs is to provide technical assistance and to ensure achievement of program goals. Project officers will conduct a site visit if a grantee is not making adequate progress toward meeting KDA project goals. Project officers discuss difficulties that the grantee is encountering and assist in determining a plan of action for addressing problems, which may include a recommendation for technical assistance. Project officers also work collaboratively with study sites to oversee project design, analysis, and reporting of results. 
Reviews of Audit Reports and Grant Applications Are Also Used to Monitor Compliance
SAMHSA also reviews grantees' annual financial audits and grant applications to ensure compliance with program requirements. According to SAMSHA officials, the agency's primary fiscal monitoring mechanism for grantees is the agency's review of annual financial audit reports required by the Single Audit Act. In general, the single audit is designed to determine if a grantee's financial statements are fairly presented and grant funds are managed in accordance with applicable laws and program requirements. Under criteria established in the act, independent auditors use expenditure limits and risk-based guidelines to identify the programs that will be audited. ${ }^{9}$ Therefore, if a grantee's SAPT or KDA program expenditures in a given year fall below the audit threshold of $\$ 300,000$ - or 3 percent of total federal expenditures- the program is generally not audited in that year. In 1997, 13 SAPT block grantees were not audited.

SAMHSA officials reported using their reviews of independent financial audit reports to identify grantees that need to take corrective actions to come into compliance with program requirements. For example, if an audit report includes recommendations for resolving findings related to grantee noncompliance, SAMHSA will request a corrective action plan from the grantee for each recommendation and review grantee submissions for adequate responses. If a grantee does not submit an audit report or correct audit findings in a timely manner, or material accounting and financial weaknesses are repeated in audit reports, SAMHSA has the authority to suspend or terminate the grant award, or require the grantee to submit additional financial reports as a condition of receiving additional grant funds. 
SAMHSA also uses its review of grantee applications to monitor SAPT block grant program compliance. SAMHSA project officers are responsible for reviewing SAPT block grant applications to determine if states have complied with statutory requirements, such as set-asides for special populations and maintenance of effort. SAMHSA, how ever, has approved some states' applications without addressing their reported maintenance of effort shortfalls. ${ }^{10}$ Audit report and on-site review findings as well as a subsequent internal review of grantees' fiscal years 1994 through 1996 block grant applications identified seven states that reported noncompliance with maintenance of effort requirements. If a state fails to comply with the maintenance of effort requirement, SAMHSA can reduce the state's block grant award by the amount of the shortfall or request a determination of material compliance from the Secretary of HHS. SAMHSA can also grant a waiver if the state has experienced a financial crisis. SAMHSA, however, did not follow appropriate procedures when states reported maintenance of effort shortfalls in their block grant applications. In August 1998, SAMHSA developed a plan to improve its oversight of maintenance of effort issues, which includes making maintenance of effort compliance the highest priority for initial staff review, initiating weekly status reports on states with compliance issues, and conducting internal quarterly assurance meetings to review SAPT block grant documentation.

States' Mechanisms to Monitor Use of SAPT Block Grant F unds Are Similar to SAMHSA's
The states we surveyed reported using a variety of mechanisms to monitor the use of SAPT block grant funds provided to third parties, such as counties and treatment providers. Many of these mechanisms were similar to those used by SAMHSA. Of the 16 states surveyed, 12 reported using onsite visits, financial audits of providers, management information systems, and cost and activity reports. The remaining four states used at least two of these mechanisms. Some states reported that these mechanisms were used specifically to monitor provider billing procedures, quality of care, and providers' compliance with SAPT block grant program requirements.

Most of the surveyed states reported that the results of their monitoring were used to determine provider and service contracting, funding allocations, and technical assistance needs. For example, Texas reported

\footnotetext{
${ }^{10}$ The state's principal agency for drug abuse treatment is required to maintain aggregate drug abuse treatment expenditures at a level that is not less than the average level of such expenditures for the 2-year period preceding the fiscal year for which the state is applying for the grant.
} 
delaying funding or suspending contracts for providers who were not compliant with program requirements. Washington state officials reported that monitoring results have been used to identify priority populations for receiving treatment services. Georgia officials reported that monitoring results have been used to establish policies for staff training and a process for allocating treatment funds.

SAMHSA and States Are Using Client Outcome Data to Determine the Effectiveness of Drug Abuse Treatment Services
Several efforts are under way to determine whether states receiving SAPT block grant funds are supporting effective drug abuse treatment programs. Some states are conducting studies using client outcome measures to assess the effectiveness of their programs. While SAMHSA has supported national studies that suggest drug abuse treatment is beneficial in reducing drug use, increasing employment, and reducing criminal activity, SAMHSA does not currently know the outcomes of states' drug abuse treatment programs supported with SAPT block grant funds. To determine the effect states' programs are having on drug abuse, SAMHSA believes it is critical to collect uniform state-level client outcome data. Therefore, the agency is currently conducting a pilot study with 19 states to collect such data. SAMHSA has also initiated an effort to have states voluntarily report client outcome data in their block grant applications. How ever, this effort has limitations because states do not collect data in the same way; some states do not collect the data SAMHSA requested; and, according to SAMHSA officials, some states lack the capacity to collect and report the data.

\section{SAMHSA-F unded National Studies Suggest Benefits of Drug Abuse Treatment}

SAMHSA has funded two national studies that suggest drug abuse treatment is effective at improving outcomes, such as decreasing drug use, criminal activity, and unemployment. The Services Research Outcome Study is the first national study of substance abuse treatment outcomes to include a representative sample of drug abuse treatment programs in rural, suburban, and urban locations. ${ }^{11}$ The National Treatment Improvement Evaluation Study, a 5-year study, examined the effectiveness of treatment provided in public programs supported by SAMHSA. While these two studies relied on self-reported data as the primary data collection method, 


\begin{tabular}{|c|c|c|}
\hline & Services Research Outcome Study & $\begin{array}{l}\text { National Treatment Improvement Evaluation } \\
\text { Study }\end{array}$ \\
\hline \multicolumn{3}{|l|}{ Study characteristics } \\
\hline Population & $\begin{array}{l}1,799 \text { people, representing a } 65 \text {-percent } \\
\text { simple response rate and a } 38 \text {-percent } \\
\text { cumulative response rate }^{a}\end{array}$ & $\begin{array}{l}4,411 \text { people, representing } 67 \text { percent of the total } \\
\text { number of clients in the study sample }\end{array}$ \\
\hline Measurement time frame & $\begin{array}{l}5 \text { years before treatment compared to } 5 \\
\text { years after treatment }\end{array}$ & $\begin{array}{l}1 \text { month or } 1 \text { year before treatment compared to } 1 \\
\text { month or } 1 \text { year after treatment }\end{array}$ \\
\hline Treatment service & $\begin{array}{l}\text { Hospital inpatient, residential, outpatient } \\
\text { methadone, outpatient nonmethadone }\end{array}$ & $\begin{array}{l}\text { Methadone, drug-free outpatient, short- and long- } \\
\text { term residential, correctional }\end{array}$ \\
\hline \multicolumn{3}{|c|}{ Outcome measures and results } \\
\hline Drug use & $\begin{array}{l}\text { A } 21 \text {-percent overall reduction in the number } \\
\text { of people using any illicit drug following } \\
\text { treatment. }\end{array}$ & $\begin{array}{l}\text { Drug use declined by about } 50 \text { percent for as long } \\
\text { as } 1 \text { year following treatment. }\end{array}$ \\
\hline Criminal activity & $\begin{array}{l}\text { Between 23- and 38-percent reduction for } \\
\text { most crimes, including theft, drug sales, } \\
\text { prostitution, drunk driving, and weapon use. }\end{array}$ & $\begin{array}{l}\text { Significant decreases in multiple indicators of } \\
\text { criminal involvement, such as a 64-percent } \\
\text { decrease in arrests and a 78-percent decrease in } \\
\text { selling drugs. }\end{array}$ \\
\hline Employment & $\begin{array}{l}\text { No appreciable change in the rate of full- } \\
\text { time employment for clients discharged from } \\
\text { treatment. }\end{array}$ & $\begin{array}{l}\text { Rate of employment increased by } 19 \text { percent, and } \\
\text { those on welfare decreased by almost } 11 \text { percent. }\end{array}$ \\
\hline Living arrangement & $\begin{array}{l}\text { Improved housing was secured and custody } \\
\text { of children regained after treatment. }\end{array}$ & Homelessness decreased by 43 percent. \\
\hline Physical health & (Not measured.) & $\begin{array}{l}\text { Alcohol and drug-related medical visits declined by } \\
53 \text { percent. }\end{array}$ \\
\hline Mental health & $\begin{array}{l}\text { Suicide attempts declined following } \\
\text { treatment. }\end{array}$ & $\begin{array}{l}\text { Mental health problems declined by } 35 \text { percent, } \\
\text { and inpatient mental health declined by } 28 \text { percent. }\end{array}$ \\
\hline Sexual activity & (Not measured.) & $\begin{array}{l}\text { Sex for money or drugs decreased by } 56 \text { percent, } \\
\text { and sex with an intravenous drug user decreased } \\
\text { by } 51 \text { percent. }\end{array}$ \\
\hline
\end{tabular}

'The Services Research Outcome Study's client sample was derived from a sample of treatment facilities identified in the Drug Services Research Survey, a prior study. Therefore, when the Services Research Outcome Study is viewed as a longitudinal study (that captures the facilities sample from the Drug Services Research Survey as well as its completed cases), its cumulative response rate is 38 percent-the product of the studies' response rates.

In addition to national studies, SAMHSA is trying to develop state-level data about drug abuse treatment effectiveness. The results of this effort will be 
used to monitor and report to the Congress the performance and success of individual states' drug abuse treatment programs supported with SAPT funds. While there is no specific statutory requirement for states to collect and report outcome data on the results of their treatment programs supported with SAPT block grant funds, SAMHSA officials stated that having such data is essential in determining the effect state programs have on the agency's mission of improving health and reducing illness, death, disability, and costs to society.

\section{States' Efforts to Assess Effectiveness Vary but Show Benefits of Drug Abuse Treatment}

Most states we surveyed have conducted outcome assessments of drug abuse treatment since 1994, including special studies and ongoing performance measurement, but their assessments vary in the outcomes measured, populations assessed, methodologies used, and availability of results. Seven of the 16 states we surveyed-Florida, Maryland, New York, North Carolina, Ohio, Texas, and Washington-reported that they have been mandated by state legislation to assess the outcomes of their drug abuse treatment activities. For example, North Carolina is required to establish and report performance outcomes that include abstinence from drug use. In Washington, the governor holds the Secretary of the state's Department of Social and Health Services accountable for achieving drug abuse treatment outcomes that are specifically outlined in the performance contract of the state's director for alcohol and substance abuse. All states we surveyed plan to begin assessing treatment programs using outcome measures by the year 2002 .

Of the 16 states surveyed, 9 reported having completed at least one outcome assessment and of them, 7 reported they had completed specific client outcome studies (see table 2). Seven of the nine states reported they use performance measurement data to assess drug abuse treatment effectiveness on an ongoing basis. 
Table 2: States' Client Outcome Assessment Activities

\begin{tabular}{lrr}
\hline $\begin{array}{l}\text { States reporting } \\
\text { completed outcome } \\
\text { assessments }\end{array}$ & $\begin{array}{r}\text { Conducted specific client } \\
\text { outcome study (number of } \\
\text { studies) }\end{array}$ & $\begin{array}{r}\text { Continually assess client } \\
\text { outcomes using performance } \\
\text { measurement data }\end{array}$ \\
\hline California & $X(1)$ & $X$ \\
\hline Florida & $X(1)$ & $X$ \\
\hline Georgia & $X(3)$ & $X$ \\
\hline New York & & $X$ \\
\hline North Carolina & $X(3)$ & $X$ \\
\hline Ohio & $X(5)$ & $X$ \\
\hline Texas & $X(1)$ & $X$ \\
\hline Virginia & & $X(11)$ \\
\hline Washington & & \\
\hline
\end{tabular}

These states generally use a number of outcome measures to assess their drug abuse treatment efforts, including abstinence, drug use, employment, mental and physical health, living arrangement, and criminal activity. However, the indicators for measuring these outcomes varied. For example, Ohio measures criminal activity in terms of rearrests, incarcerations, and probation violations. California measures criminal activity using several indicators that include the number of times a drug abuser sold or helped sell drugs, had sex for money or drugs, broke into a house or vehicle, or used a weapon. In addition, the surveyed states' assessments varied in terms of target populations, purpose, time frames, or other methodological issues.

Of the nine states that reported conducting outcome assessments, sixCalifornia, Florida, North Carolina, Ohio, Texas, and Washington-reported benefits as a result of drug abuse treatment. ${ }^{12}$ (See app. IV for details of the six states' outcome assessments.) For example, California has conducted a large-scale study that showed treatment reduced drug use by about 40 percent and criminal activity by about 66 percent. Washington reported that its study of treatment for impoverished populations showed that

${ }^{12}$ Georgia and New York did not provide results from their assessments; Virginia officials stated that the results from their performance outcome measurement system were ambiguous due to inconsistent data elements across programs and problems with linking the information with the state's management information system. 
quarterly earnings of clients receiving treatment were more than twice the earnings of clients not receiving treatment and that health care costs for clients receiving treatment decreased by nearly 50 percent. According to SAMHSA, the National Association of State Alcohol and Drug Abuse Directors, and substance abuse experts, Washington and New York are examples of states from which lessons could be learned about measuring the effectiveness of drug abuse treatment using client outcomes. For example, Washington's data system uses Social Security numbers to track clients, enabling the state to integrate self-reported data with secondary databases, including state employment and welfare rolls, to provide objective data for measuring client outcomes. ${ }^{13}$ Washington reported conducting 12 outcome assessment activities since 1994 and using client identifiers and integrative techniques for the past 7 to 8 years. New York officials reported using an integrated program monitoring and evaluation system since 1995 to assess the performance of all drug abuse treatment providers. This system uses 12 performance measures, including abstinence and employment, and has an established set of minimum performance standards. Drug abuse treatment providers who do not meet the standards are required to develop an action plan to meet the minimum performance standards.

SAMHSA's Pilot Effort Assists 19 States in Developing and Collecting Uniform State Outcome Data
SAMHSA has initiated efforts to improve existing state data systems to make them comparable for performance measurement. Specifically, in 1997, SAM HSA developed the Treatment Outcomes and Performance Pilot Studies (TOPPS) to help states develop or enhance their management information systems and outcome monitoring systems for evaluating clients receiving treatment. In 1998, SAMHSA created a grant program to further this effort-the Treatment Outcomes and Performance Pilot Studies E nhancement (TOPPS II) - which is being conducted under cooperative agreements with 19 states, ${ }^{14}$ including 9 that we surveyed. TOPPS II aims to help the pilot states collect information on SAPT-funded treatment services and monitor a core set of substance abuse treatment effectiveness measures. Several of the states we surveyed reported this

\footnotetext{
${ }^{13}$ Washington law allows the use of Social Security numbers to track clients; however, some states prohibit the use of these identifiers because of privacy and access concerns.

${ }^{14}$ The 19 states that applied and were selected to participate in TOPPS II are Arizona, Arkansas, California, Connecticut, Illinois, Iowa, Kentucky, Maryland, Massachusetts, Missouri, New Hampshire, New J ersey, New York, Oklahoma, Rhode Island, Texas, Utah, Virginia, and Washington.
} 
program as part of their assessment efforts to measure drug abuse treatment effectiveness.

While the TOPPS initiative supported individually designed state studies to assess treatment effectiveness, TOPPS II supports a consensus-developed set of common client outcome measures of treatment effectiveness and incorporation of these measures into the databases of participating states. Both SAMHSA and the states participating in TOPPS II agreed on a core set of outcome measures that include substance abuse, health services utilization, self-help participation, pregnancy and status of children, employment status, living arrangements, and criminal behavior. As a condition of receiving funding through TOPPS II, each of the 19 participating states is required to report to SAMHSA on each of these measures of treatment effectiveness. The TOPPS II study will issue interim and final reports that summarize developments and findings in the state and interstate evaluations. States are to report final results to SAMHSA in September 2001.

\section{SAMHSA's Effort to Collect Outcome Data From All States Will Not Provide Uniform Data}

SAMHSA is asking states to voluntarily report on a core set of outcome measures-drug use, criminal activity, employment status, and living arrangements-in the fiscal year 2000 SAPT block grant application. ${ }^{15} \mathrm{~F}$ or programs supported with SAPT block grant funds, SAMHSA is asking states to report the percent change in each measure that has occurred between admission and discharge for clients completing treatment, by age and race/ethnicity, using specific indicators such as arrests and homelessness. ${ }^{16}$ Further, SAMHSA is asking states to report the source of the data, reasons for not being able to report the data, and whether information is available to measure outcomes after treatment is completed.

SAMHSA's effort to have all states voluntarily report outcome data in their fiscal year 2000 SAPT block grant application, however, will not yield consistent and uniform data across states because some states reported that they are not currently collecting all the outcome data that SAMHSA is requesting. Of the 16 states we surveyed, 8 plan to report data on some of

\footnotetext{
${ }^{15}$ SAMHSA's core set of outcome measures also include alcohol use.

${ }^{16}$ One expert we spoke with stated that it is also important to collect a core set of clinical data at client admissions to help establish an evaluation database and that such a database could be hel pful in standardizing treatment approaches and training of personnel in the drug abuse treatment field.
} 
the outcome measures; 4 of these states-California, Maryland, New York, and Washington-are participating in SAMHSA's TOPPS II program. For example, Georgia officials stated that they will report outcome information to SAMHSA in the fiscal year 2000 block grant application but do not have the data needed to report outcomes by race and age as requested by SAMHSA. The remaining eight states we surveyed reported that they will not or are unsure whether they will report the outcome information because they are not currently collecting much of the data SAMHSA requested.

SAMHSA officials are still reviewing applications and said that they are unsure of the extent to which states will report complete and consistent client outcome information in their SAPT block grant applications. SAMHSA plans to use the information it collects to identify states' ability to report outcome data, such as the availability of state outcome data, the complexities of measuring client outcomes, and states' infrastructure needs for measuring outcomes. SAMHSA officials stated that improving states' ability to collect client outcomes and requiring them to report on a uniform set of measures would enhance SAMHSA's ability to obtain uniform and consistent client outcome data across states. In November 1999, HHS' general counsel, together with SAMHSA officials, determined that the Secretary of HHS has the authority to require such information for administering the program. However, according to SAMHSA officials, it is highly unlikely that the states could currently report the quality of data needed to make accurate program assessments. abuse treatment through the SAPT block grant program. While SAMHSA monitors state expenditures to determine whether block grant funds are used in accordance with statutory requirements, this type of monitoring is not designed to determine the effect state drug abuse treatment programs are having on client outcomes. Assessing the effectiveness of drug abuse treatment is important in ensuring federal and state accountability for program results. Some states are assessing the effectiveness of their treatment programs using various outcome indicators. SAMHSA officials believe that the collection of uniform state-level client outcome data is essential for determining the effectiveness of drug abuse treatment programs supported with federal funds and for reporting the information to the Congress. SAMHSA is trying to determine the availability of client outcome data from all states and has awarded grants to some states to help improve their data collection systems. These efforts should help identify 
states' views about and some of the complexities associated with collecting and reporting client outcome data. SAMHSA's efforts should also help to determine what additional actions are needed to get uniform state reporting on the results of drug abuse treatment programs supported with SAPT block grant funds.

\section{Agency and Other Comments}

We provided a draft of this report to SAMHSA and the 16 states we surveyed. SAMHSA officials said that the report provided an accurate and thorough review of the agency's SAPT block grant and KDA grant programs. SAMHSA and some of the 14 states that responded to our request for comments had additional information, clarifications, and technical comments, which we incorporated where appropriate.

As agreed with your office, unless you publicly announce its contents earlier, we plan no further distribution of this report until 5 days from the date of this letter. At that time, we will send copies to the Honorable Donna E. Shalala, Secretary of HHS; the Honorable Nelba Chavez, Administrator of SAMHSA; officials of the state substance abuse agencies we surveyed; appropriate congressional committees; and other interested parties. We will also make copies available to others upon request.

Please contact me at (202) 512-7119 or J ames O. McClyde, Assistant Director, at (202) 512-7152, if you or your staff have any questions. Other major contributors to this report were Veronica Henry and J anina J ohnson.

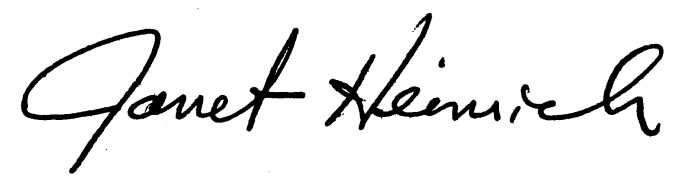

J anet Heinrich

Associate Director, Health Financing and Public Health Issues 
B-281927 
In response to congressional concern about how federal drug abuse treatment funds are accounted for and whether they support effective drug abuse treatment programs, we were asked to describe the activities supported by SAMHSA's SAPT block grant and KDA grant funds for drug abuse treatment, the mechanisms SAMHSA and states have in place to monitor fund use, and SAMHSA and state efforts to determine the effectiveness of drug abuse treatment supported with SAPT block grant funds.

To conduct our work on SAMHSA's SAPT block grant program, we surveyed 16 states-California, Florida, Georgia, Illinois, Indiana, Maryland, Massachusetts, Michigan, New Jersey, New York, North Carolina, Ohio, Pennsylvania, Texas, Virginia, and Washington-and conducted follow-up interviews with selected respondents. We selected these states because they received at least $\$ 25$ million for their fiscal year 1996 SAPT block grant award; further, substance abuse experts and knowledgeable officials identified some of these states as having wellestablished systems for collecting outcome data and assessing their drug abuse treatment programs. Our review focused on expenditures of fiscal year 1996 drug abuse treatment funds because it is the most recent year for which complete expenditure data are available on the SAPT block grant from SAMHSA and the states. States have 2 years to spend their SAPT block grant award and generally report expenditures in the third year.

Through our survey and interviews, we collected information on (1) grantees' expenditures for the different categories of drug abuse treatment services states report in their annual SAPT block grant applicationsresidential, outpatient, detoxification, and methadone; (2) the mechanisms used to monitor the use of these grant expenditures; and (3) assessments of drug abuse treatment effectiveness conducted since 1994 using client outcomes, including measuring performance on an ongoing basis or through periodic special studies. We asked states to exclude their use of SAPT block grant funds for other activities, such as alcohol treatment and prevention, from their survey responses.

We also interviewed officials in SAMHSA's Center for Substance Abuse Treatment, Office of Program Services, and Office of Applied Studies, and reviewed documents they provided on (1) SAPT block grant and KDA grant activities funded with drug abuse treatment dollars; (2) mechanisms SAMHSA uses to monitor grantees' use of funds and compliance with program requirements; ( 3 ) efforts to assess the effectiveness of treatment using client outcomes; and (4) SAMHSA's administrative expenses, 
including contracts and staffing levels. In addition, we obtained the views of officials at the National Association of State Alcohol and Drug Abuse Directors and experts in the substance abuse research community on assessing the effectiveness of drug abuse treatment using client outcomes.

Although the 16 states we selected to survey represented about 70 percent of fiscal year 1996 SAPT block grant awards and 60 percent of SAPT block grant drug abuse treatment expenditures for services, the results of our survey are not necessarily generalizable to the nation. Also, some survey states provided estimates of drug abuse treatment expenditures because they could not separate drug from alcohol abuse treatment services or could not isolate SAPT block grant expenditures from their total drug abuse treatment expenditures. We did not independently verify the accuracy of grantees' drug abuse treatment expenditures. How ever, we compared some of the expenditure data reported in our survey with grantee expenditures reported to SAMHSA in their approved SAPT block grant applications and found no material differences. We did our work from J anuary 1999 to J anuary 2000 in accordance with generally accepted government auditing standards. 
In October 1992, the Congress established SAMHSA under Public Law 102321 to strengthen the nation's health care delivery system for prevention and treatment of substance abuse and mental illnesses. Specifically, SAMHSA was to develop national goals and model programs; coordinate federal policy related to providing prevention and treatment services; and evaluate the process, outcomes, and community impact of prevention and treatment services. B efore 1992, the major federal substance abuse and mental health delivery services and research activities were combined under one agency, the Alcohol, Drug Abuse, and Mental Health Administration. In the 1992 legislation, the Congress created SAMHSA to administer the services portion of the former agency and transferred its research components to the $\mathrm{N}$ ational Institutes of Health to be carried out by the National Institute on Alcohol Abuse and Alcoholism, NIDA, and the National Institute of Mental Health.

Since 1992, SAMHSA's budget has remained relatively stable at about $\$ 2$ billion each year. SAMHSA's fiscal year 1999 budget was about $\$ 2.5$ billion for substance abuse treatment and prevention and mental health services. About $\$ 1.6$ billion was for the SAPT block grant program-95 percent of which is allocated to states and local governments. SAMHSA allocated another $\$ 329$ million to fund prevention and treatment discretionary grant programs. A portion of SAMHSA's budget is appropriated for administrative expenses-about 6 percent ( $\$ 155$ million) for fiscal year 1999 . The majority of the administrative expense appropriation supports contractual services that include technical assistance and program evaluation activities. Administrative expenses also support personnel compensation. As of December 1999, SAMHSA employed a total of 538 people, who are centrally located in the Washington, D.C., metropolitan area. The remaining administrative funds support costs related to travel, communications, printing, supplies, and rental payments. Table 3 lists SAMHSA's fiscal year 1999 appropriated amounts for administrative expenses; table 4 describes selected SAMHSA fiscal year 1999 contracts for technical assistance and program evaluation; and table 5 lists SAMHSA's staffing levels by program as of December 1999. 
Appendix II

History and Administration of SAMHSA

Table 3: SAMHSA's Administrative Expenses, Fiscal Year 1999 Appropriation

\begin{tabular}{lr}
\hline Administrative expenses & $\begin{array}{r}\text { Fiscal year 1999 } \\
\text { appropriation }\end{array}$ \\
\hline Personnel compensation and benefits & $\$ 47,031,000$ \\
\hline Printing and reproduction & $3,608,000$ \\
\hline Communications, utilities, and miscellaneous charges & $1,401,000$ \\
\hline Travel & $1,199,000$ \\
\hline Supplies and materials & 392,000 \\
\hline Transportation of things & 105,000 \\
\hline Rental payments & 40,000 \\
\hline Other contractual services $^{\mathrm{a}}$ & $101,576,000$ \\
\hline Total & $\mathbf{\$ 1 5 5 , 3 5 2 , 0 0 0}$ \\
\hline
\end{tabular}

${ }^{a}$ Excludes about $\$ 62$ million in contractual services related to SAMHSA's block grant set-asides, drug surveys, and program evaluation; includes indirect costs estimated at 19.5 percent, with contractor fees of 5.1 percent.

Source: HHS Fiscal Year 2000 Substance Abuse and Mental Health Services Administration Justification of Estimates for Appropriations Committees. 
Table 4: Selected SAMHSA Contracts for Technical Assistance and Program Evaluation, Fiscal Year 1999, by Agency and Program

\section{Contractor \\ Description}

Amount

\section{Center for Substance Abuse Treatment}

\section{SAPT Block Grant}

\section{Johnson, Bassin \& Shaw,}

Inc., Silver Spring, Md.

Health Systems Research, Inc. Washington, D.C.
Help states prepare technical assistance plans to resolve deficiencies identified in on-site technical reviews, and improve linkages between the drug abuse treatment system and other social service systems.

Provide technical assistance to maintain the Treatment Improvement Exchange

$1,088,632$ database, logistical assistance for meetings, and editorial expertise for reports and documents.

\section{KDA/Targeted Capacity Expansion}

R.O.W. Sciences, Inc.,

Rockville, Md.
Provide technical assistance and support of KDA grants funded in fiscal years 1996 through 1998 and 2000 through 2002, and ongoing demonstration programs of the Center for Substance Abuse Treatment's Division of Practice and Systems Development.

CDM/JBS Joint Venture, Chevy Chase, Md. Establish a program to ensure that knowledge developed by projects funded by the Center for Substance Abuse Treatment is disseminated to substance abuse treatment and related fields.

Johnson, Bassin \& Shaw, Inc., Silver Spring, Md.

Provide support for a coordinating center to facilitate transfer of business and management technology to organizations and entities that make up the public sector treatment system.

Caliber Associates, Fairfax, Primarily provide support for the Residential Women and Children, Pregnant and Va. Postpartum Women and Children, and HIV Outreach programs' cross-site evaluation initiatives, and provide selected technical assistance to KDA grantees.

Caliber Associates, Fairfax, Provide a wide array of data management and scientific support across various Va. programmatic and evaluation activities, including grants, cooperative agreements, and contracts.

Birch \& Davis Associates, Inc., Silver Spring, Md.

Provide technical assistance for the Targeted Capacity Expansion cross-site evaluation, including support for implementing data collection systems, conducting data analyses, and preparing reports.

Johnson, Bassin \& Shaw, Inc., Silver Spring, Md. Develop a field evaluation of the treatment improvement protocols in order to assess treatment provider awareness and implementation, and to evaluate the effects of the protocols on the process and outcomes of addiction treatment.

The Medstat Group, Inc., Develop an integrated database of mental health and substance abuse treatment Washington, D.C. services spending estimates that will allow for comparisons to national health expenditures.
$3,635,571$

$3,504,201$ 


\begin{tabular}{|c|c|c|}
\hline Contractor & Description & Amount \\
\hline \multicolumn{3}{|c|}{ Center for Substance Abuse Prevention } \\
\hline \multicolumn{3}{|l|}{ SAPT Block Grant } \\
\hline $\begin{array}{l}\text { Johnson, Bassin \& Shaw, } \\
\text { Inc., Silver Spring, Md. }\end{array}$ & $\begin{array}{l}\text { Provide technical assistance to states on complying with SAPT block grant } \\
\text { requirements and developing systems to administer successful and cost-effective } \\
\text { prevention services, and support on-site monitoring of states' block grant funds } \\
\text { and programs. }\end{array}$ & $3,584,997$ \\
\hline $\begin{array}{l}\text { Research Foundation, John } \\
\text { Jay College, CUNY, New } \\
\text { York, N.Y. }\end{array}$ & $\begin{array}{l}\text { Assist with developing and disseminating knowledge about what works in } \\
\text { prevention and making available to states and the field useful tools for developing } \\
\text { prevention plans, making resource allocation decisions, implementing appropriate } \\
\text { and effective prevention programs, and satisfying demands for public } \\
\text { accountability. }\end{array}$ & $3,469,057$ \\
\hline $\begin{array}{l}\text { Macro International, Inc., } \\
\text { Calverton, Md. }\end{array}$ & $\begin{array}{l}\text { Assist states in the development of data systems designed to monitor prevention } \\
\text { service delivery. }\end{array}$ & $1,333,586$ \\
\hline \multicolumn{3}{|l|}{ KDA } \\
\hline CRP, Inc., Washington, D.C. & $\begin{array}{l}\text { This contract carries out the Corporate Alliance on Drug Education earmark, which } \\
\text { has been included within the center's budget for the past several years. It also } \\
\text { provides SAMHSA logistical support, including training and technical assistance } \\
\text { on evaluating prevention programs. }\end{array}$ & $1,703,145$ \\
\hline $\begin{array}{l}\text { Caliber Associates, Fairfax, } \\
\text { Va. }\end{array}$ & $\begin{array}{l}\text { Assist the Center for Substance Abuse Prevention with coordinating program data } \\
\text { and producing analytic reports. Contract also includes monitoring and analyzing } \\
\text { performance measurements. }\end{array}$ & $1,498,708$ \\
\hline $\begin{array}{l}\text { EMT Associates Inc., } \\
\text { Folsom, Calif. }\end{array}$ & $\begin{array}{l}\text { Conduct a process and outcome evaluation of } 47 \text { high-risk substance abuse } \\
\text { prevention programs for youth, funded in } 1994 \text { and } 1995 .\end{array}$ & $1,168,057$ \\
\hline $\begin{array}{l}\text { The CDM Group, Inc., } \\
\text { Chevy Chase, Md. }\end{array}$ & $\begin{array}{l}\text { Assist with developing, collecting, and analyzing outcome measures across } \\
\text { Workplace Managed Care program grantees; support the planning, development, } \\
\text { and implementation of a series of specialized work groups and meetings on } \\
\text { workplace issues. }\end{array}$ & $1,086,895$ \\
\hline
\end{tabular}

\section{Center for Mental Health Services}

\section{Children's Programs}

American Institute for Research, Washington, D.C.

Provide grantees of the Comprehensive Community Mental Health Services for Children and Their Families Program with training and technical assistance for developing community-based and family-focused services and integrating child and family services into local comprehensive systems of care.

Macro International, Inc., Assess the effectiveness of the systems of care created by the Comprehensive

Calverton, Md.

Community Mental Health Services Program for Children and Adolescents, as required by statute. This funding was for evaluations of 26 grantees.

Macro International, Inc., Assess the effectiveness of the systems of care created by the Comprehensive

Calverton, Md. Community Mental Health Services Program for Children and Adolescents, as required by statute. This funding was for evaluations of 20 grantees.

Vanguard Communications Develop and implement a community-based, local and national marketing of Falls Church, Washington, D.C. campaign, and disseminate campaign messages and products to reduce the mental health stigma.

Macro International, Inc., Continue the evaluation of the Comprehensive Community Mental Health Services

Calverton, Md.

Program for Children and Adolescents focusing on services for children and adolescents with serious emotional disturbances.

adolescents with serious emotional disturbances.


Appendix II

History and Administration of SAMHSA

\begin{tabular}{|c|c|c|}
\hline Contractor & Description & Amount \\
\hline $\begin{array}{l}\text { American Institute for } \\
\text { Research, Washington, } \\
\text { D.C. }\end{array}$ & $\begin{array}{l}\text { Evaluate children's mental health in urban communities, including state } \\
\text { commitments to mental health services programs and integration of family- } \\
\text { centered concepts and teaching strategies in medical education. }\end{array}$ & $1,064,853$ \\
\hline \multicolumn{3}{|l|}{ KDA } \\
\hline $\begin{array}{l}\text { The Gallup Organization, } \\
\text { Rockville, Md. }\end{array}$ & $\begin{array}{l}\text { Provide support for the School Violence Prevention grantee sites by developing } \\
\text { products and activities to communicate with primary and secondary target } \\
\text { audiences, and enhance awareness, understanding, and application of strategies } \\
\text { aimed at school violence prevention and healthy child development. }\end{array}$ & $2,006,000$ \\
\hline $\begin{array}{l}\text { R.O.W. Sciences, Inc., } \\
\text { Rockville, Md. }\end{array}$ & $\begin{array}{l}\text { Evaluate the Access to Community Care and Effective Services and Support } \\
\text { Demonstration Program for Homeless Persons with Serious Mental Health } \\
\text { Illnesses. }\end{array}$ & $1,399,880$ \\
\hline \multicolumn{3}{|l|}{ Mental Health Block Grant } \\
\hline $\begin{array}{l}\text { Masimax Resources, Inc., } \\
\text { Rockville, Md. }\end{array}$ & $\begin{array}{l}\text { Provide support for the Mental Health Statistical Improvement Program, } \\
\text { specifically the policy group, operations of task forces, regional and decision } \\
\text { application groups, and further development of the managed care data system. }\end{array}$ & $1,196,093$ \\
\hline \multicolumn{3}{|l|}{ Office of Program Services } \\
\hline $\begin{array}{l}\text { Orkand Corporation, Falls } \\
\text { Church, Va. }\end{array}$ & $\begin{array}{l}\text { Provide support for local area network operation, microcomputer technical } \\
\text { services, software training, ADP technical studies, and database administration. }\end{array}$ & $1,449,921$ \\
\hline \multicolumn{3}{|l|}{ Office of Applied Studies } \\
\hline Westat, Inc., Rockville, Md. & $\begin{array}{l}\text { Assess the value of the Drug Abuse Warning Network in relation to the needs of its } \\
\text { users and make recommendations for an alternative design. }\end{array}$ & $1,000,000$ \\
\hline \multicolumn{3}{|c|}{ Office of Planning and Program Coordination } \\
\hline $\begin{array}{l}\text { MayaTech Corporation, } \\
\text { Silver Spring, Md. }\end{array}$ & $\begin{array}{l}\text { Provide technical, administrative, and logistical support for peer review meetings } \\
\text { that evaluate grant applications and contract proposals. }\end{array}$ & $1,000,000$ \\
\hline
\end{tabular}

Note: These contracts represent $\$ 64$ million, or 64 percent, of contracts SAMHSA specifically identified for technical assistance and program evaluation and account for those contracts in fiscal year 1999 whose dollar values are $\$ 1$ million or greater. There were 95 other contracts with values less than $\$ 1$ million funded in fiscal year 1999. 
Table 5: SAMHSA's Staffing Levels by Program, as of December 1999

\begin{tabular}{|c|c|c|c|c|}
\hline Program and activity & Executive staff & $\begin{array}{r}\text { Grade-level staff } \\
\text { (GS-1 to GS-15) }\end{array}$ & $\begin{array}{r}\text { Commissioned } \\
\text { officers }\end{array}$ & Total \\
\hline \multicolumn{5}{|l|}{ Center for Substance Abuse Treatment } \\
\hline KDA/targeted capacity expansion & 0 & 55 & 4 & $\overline{59}$ \\
\hline SAPT block grant ${ }^{a}$ & 0 & 21 & 5 & 26 \\
\hline Public communications $^{b}$ & 0 & 7 & 0 & $\overline{7}$ \\
\hline Program support & 0 & 6 & 0 & 6 \\
\hline Program planning/advisory councils & 0 & 10 & 1 & $\overline{11}$ \\
\hline Center management & 2 & 4 & 0 & 6 \\
\hline Total staffing & 2 & $\begin{array}{r}103 \\
5 s ; 26 \text { GS-14s; } 32 \\
\text { and 29 GS-12s or } \\
\text { lower) }\end{array}$ & 10 & 115 \\
\hline \multicolumn{5}{|l|}{ Center for Substance Abuse Prevention } \\
\hline KDA/targeted capacity expansion/high-risk youth & 1 & 33 & 2 & 36 \\
\hline SAPT block grant ${ }^{a}$ & 0 & 19 & 1 & 20 \\
\hline Other substance abuse programs ${ }^{c}$ & 0 & 17 & 0 & $\overline{17}$ \\
\hline Public communications $^{\text {b }}$ & 0 & 21 & 1 & 22 \\
\hline Program support & 0 & 4 & 0 & 4 \\
\hline Program planning/advisory councils & 0 & 11 & 1 & $\overline{12}$ \\
\hline Center management & 1 & 5 & 1 & 7 \\
\hline Total staffing & 2 & $\begin{array}{r}110 \\
5 s ; 29 \text { GS-14s; } 36 \\
\text { and 34 GS-12s or } \\
\text { lower) }\end{array}$ & 6 & $\overline{118}$ \\
\hline \multicolumn{5}{|l|}{ Center for Mental Health Services } \\
\hline $\mathrm{KDA}$ & 0 & 42 & 2 & $\overline{44}$ \\
\hline Mental health block grant ${ }^{\mathrm{a}}$ & 1 & 12 & 0 & $\overline{13}$ \\
\hline Children's program & 0 & 10 & 0 & 10 \\
\hline Homeless programs $^{d}$ & 0 & 2 & 0 & 2 \\
\hline Protection advocacy & 0 & 1 & 0 & $\overline{1}$ \\
\hline Other mental health programs $^{\mathrm{e}}$ & 0 & 11 & 1 & $\overline{12}$ \\
\hline Public communications $^{b}$ & 0 & 10 & 3 & 13 \\
\hline Program support & 0 & 8 & 1 & 9 \\
\hline Center management & 1 & 7 & 1 & 9 \\
\hline
\end{tabular}


Appendix II

History and Administration of SAMHSA

\begin{tabular}{|c|c|c|c|c|}
\hline Program and activity & Executive staff & $\begin{array}{r}\text { Grade-level staff } \\
\text { (GS-1 to GS-15) }\end{array}$ & $\begin{array}{r}\text { Commissioned } \\
\text { officers }\end{array}$ & Total \\
\hline Total staffing & 2 & $\begin{array}{r}103 \\
5 \mathrm{~s} ; 27 \text { GS-14s; } 29 \\
\text { and } 35 \text { GS-12s or } \\
\text { lower) }\end{array}$ & 8 & 113 \\
\hline \multicolumn{5}{|l|}{ Office of the Administrator } \\
\hline Operating division/public communications ${ }^{\mathrm{b}}$ & 0 & 12 & 0 & 12 \\
\hline Grants/contract review ${ }^{f}$ & 0 & 10 & 3 & $\overline{13}$ \\
\hline Other operating division/crosscutting programs ${ }^{g}$ & 0 & 19 & 1 & 20 \\
\hline Program planning/coordination & 1 & 8 & 0 & 9 \\
\hline Operating division management ${ }^{\mathrm{h}}$ & 3 & 16 & 0 & $\overline{19}$ \\
\hline Total staffing & 4 & $\begin{array}{r}65 \\
5 \mathrm{~s} ; 14 \text { GS-14s; } 14 \\
\text { and } 24 \text { GS-12s or } \\
\text { lower) }\end{array}$ & 4 & 73 \\
\hline \multicolumn{5}{|l|}{ Other SAMHSA Offices } \\
\hline Office of Program Services ${ }^{i}$ & 1 & $\begin{array}{r}91 \\
5 s ; 14 \text { GS-14s; } 26 \\
\text { and } 44 \text { GS-12s or } \\
\text { lower) }\end{array}$ & 0 & 92 \\
\hline Office of Applied Studies & 1 & $\begin{array}{r}26 \\
-15 \mathrm{~s} ; 11 \mathrm{GS}-14 \mathrm{~s} ; 5 \\
\text { s; and } 4 \text { GS-12s or } \\
\text { lower) }\end{array}$ & 0 & 27 \\
\hline Total & 12 & 498 & 28 & 538 \\
\hline
\end{tabular}

${ }^{a}$ The number of staff assigned to block grant programs represents only those staff who work directly on the programs in the centers' divisions of state programs. However, numerous other staff support block grant programs directly or indirectly, including statistical staff who calculate state allocations and budget support, grants management, and audit staff.

${ }^{\mathrm{b}}$ Includes development of program materials, prevention communications, public information clearinghouses, public service messages.

'Includes minority health concerns, workplace programs, and managed care programs.

dIncludes Projects for Assistance in Transition From Homelessness Program, a formula grant program.

eIncludes emergency programs, clinical training pay back, monitoring, managed care, surgeon general's report, and bioterrorism.

fConducted within the Division of Extramural Activities, Policy, and Review.

Includes minority health program, women's health program, HIV/AIDS program, managed care program, and alcohol program.

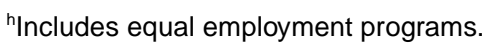

'Includes grants management, contracts management, financial management, information resources management, human resources management, and administrative services. 


\section{KDA Grant Programs and Funding for Drug Abuse Treatment}

\begin{tabular}{|c|c|c|c|c|c|}
\hline \multirow[b]{2}{*}{ Program } & \multirow[b]{2}{*}{ Description } & \multicolumn{2}{|c|}{ Fiscal year 1996} & \multicolumn{2}{|c|}{ Fiscal year 1998} \\
\hline & & Grantees & Funding & Grantees & $\overline{\text { Funding }}$ \\
\hline Target Cities & $\begin{array}{l}\text { Help metropolitan areas increase the effectiveness of } \\
\text { treatment delivery by developing a model infrastructure } \\
\text { to expand and coordinate local health care and social } \\
\text { service delivery systems with specialized addiction } \\
\text { treatment networks. }\end{array}$ & 10 & $\$ 20,340,000$ & 7 & $\$ 1,526,448$ \\
\hline $\begin{array}{l}\text { Targeted Capacity } \\
\text { Expansion }\end{array}$ & $\begin{array}{l}\text { Address gaps in treatment capacity by supporting rapid } \\
\text { and strategic responses to demands for substance } \\
\text { abuse treatment services. }\end{array}$ & $\mathrm{a}$ & a & 41 & $23,731,977$ \\
\hline $\begin{array}{l}\text { Recovery } \\
\text { Community Support }\end{array}$ & $\begin{array}{l}\text { Foster participation of those who are recovering from } \\
\text { substance abuse in the development of substance abuse } \\
\text { treatment services and programs, policies, and quality } \\
\text { assurance activities at the state and local levels. }\end{array}$ & $a$ & $\mathrm{a}$ & 19 & $3,661,892$ \\
\hline $\begin{array}{l}\text { Wraparound } \\
\text { Services }\end{array}$ & $\begin{array}{l}\text { Evaluate the benefits and cost-effectiveness of these } \\
\text { services as they relate to substance abuse treatment } \\
\text { given changes in health care financing, including } \\
\text { managed care. }\end{array}$ & 1 & $1,196,733$ & 1 & $2,004,823$ \\
\hline Welfare-to-Work & $\begin{array}{l}\text { Study the effectiveness of a program for substance- } \\
\text { busing women eligible for Temporary Assistance to } \\
\text { Needy Families to receive treatment for alcohol and/or } \\
\text { drug addiction and to become employed. }\end{array}$ & $\mathrm{a}$ & $\mathrm{a}$ & 1 & 300,000 \\
\hline $\begin{array}{l}\text { Residential Women } \\
\text { and Children }\end{array}$ & $\begin{array}{l}\text { Establish a more effective continuum of care by } \\
\text { integrating substance abuse services with general health } \\
\text { care, providing comprehensive services for addicted } \\
\text { women and their children. }\end{array}$ & 26 & $16,524,873$ & 15 & $13,804,411$ \\
\hline $\begin{array}{l}\text { Pregnant and } \\
\text { Postpartum Women }\end{array}$ & $\begin{array}{l}\text { Expand the availability of comprehensive treatment } \\
\text { services for pregnant and postpartum women and their } \\
\text { children with alcohol and other drug use problems. }\end{array}$ & 17 & $14,875,127$ & 4 & $2,893,776$ \\
\hline $\begin{array}{l}\text { Violence Against } \\
\text { Women }\end{array}$ & $\begin{array}{l}\text { Generate and apply empirical knowledge about the } \\
\text { development and effectiveness of an integrated systems } \\
\text { approach for assisting women with co-occurring } \\
\text { disorders and their children. }\end{array}$ & $\mathrm{a}$ & $\mathrm{a}$ & 9 & $5,229,228$ \\
\hline $\begin{array}{l}\text { Starting Early } \\
\text { Starting Smart }\end{array}$ & $\begin{array}{l}\text { Test the effectiveness of integrating mental health and } \\
\text { substance abuse prevention and treatment services with } \\
\text { primary health care or early childhood service settings } \\
\text { for children from birth to age } 7 \text { and their families. }\end{array}$ & a & a & 12 & $2,575,567$ \\
\hline $\begin{array}{l}\text { Children's Mental } \\
\text { Health Services }\end{array}$ & $\begin{array}{l}\text { Adjunct to the Criminal Justice Networks Program to } \\
\text { provide supplemental funds to existing Center for Mental } \\
\text { Health Services' programs that support community- } \\
\text { based substance abuse and mental health services for } \\
\text { children and families. }\end{array}$ & $\mathrm{a}$ & a & 1 & 99,749 \\
\hline $\begin{array}{l}\text { Addiction } \\
\text { Technology Transfer } \\
\text { Centers }\end{array}$ & $\begin{array}{l}\text { Network of centers to ensure that treatment } \\
\text { professionals have the latest information on best } \\
\text { practices and treatment techniques. }\end{array}$ & 11 & $7,148,339$ & 15 & $7,565,505$ \\
\hline
\end{tabular}


Appendix III

KDA Grant Programs and F unding for Drug

Abuse Treatment

\begin{tabular}{|c|c|c|c|c|c|}
\hline \multirow[b]{2}{*}{ Program } & \multirow[b]{2}{*}{ Description } & \multicolumn{2}{|c|}{ Fiscal year 1996} & \multicolumn{2}{|c|}{ Fiscal year 1998} \\
\hline & & Grantees & Funding & Grantees & Funding \\
\hline $\begin{array}{l}\text { Criminal Justice } \\
\text { Treatment Networks }\end{array}$ & $\begin{array}{l}\text { Link metropolitan justice agencies with substance abuse } \\
\text { treatment networks and related health, mental health, } \\
\text { and social services agencies. }\end{array}$ & 7 & $6,074,987$ & 7 & $8,148,230$ \\
\hline $\begin{array}{l}\text { Criminal Justice Jail } \\
\text { Diversion }\end{array}$ & $\begin{array}{l}\text { Support the evaluation of the relative effectiveness of a } \\
\text { variety of pre- and post-booking police diversion and } \\
\text { criminal justice intervention models for individuals with } \\
\text { co-occurring disorders. }\end{array}$ & $\mathrm{a}$ & $\mathrm{a}$ & 7 & $2,999,999$ \\
\hline HIV Outreach & $\begin{array}{l}\text { Modify behavior and reduce the incidence of HIV and } \\
\text { related diseases by targeting high-risk substance } \\
\text { abusers and their partners. }\end{array}$ & 11 & $3,406,999$ & $\mathrm{a}$ & \\
\hline $\begin{array}{l}\text { HIV/AIDS Cost } \\
\text { Study }\end{array}$ & $\begin{array}{l}\text { Collaboration among six federal agencies to study } \\
\text { integrated mental health, substance abuse, and primary } \\
\text { medical HIV treatment interventions. }\end{array}$ & $a$ & $\mathrm{a}$ & 9 & 950,000 \\
\hline $\begin{array}{l}\text { Managed Care- } \\
\text { Vulnerable } \\
\text { Populations }\end{array}$ & $\begin{array}{l}\text { Enhance knowledge about how managed care in the } \\
\text { public sector affects the provision of substance abuse } \\
\text { and mental health services. }\end{array}$ & 7 & $3,234,846$ & 6 & $3,357,520$ \\
\hline $\begin{array}{l}\text { Managed Care- } \\
\text { Adolescents }\end{array}$ & $\begin{array}{l}\text { Examine the effects on cost, utilization, and outcomes of } \\
\text { different models of managed care for adolescents with } \\
\text { substance abuse problems. }\end{array}$ & $\mathrm{a}$ & $\mathrm{a}$ & 7 & $4,177,676$ \\
\hline $\begin{array}{l}\text { Managed Care- } \\
\text { Alcohol Services }\end{array}$ & $\begin{array}{l}\text { Evaluate the effectiveness of alcoholism services } \\
\text { delivery in a managed care environment. }\end{array}$ & a & a & 1 & 199,999 \\
\hline $\begin{array}{l}\text { Rural Remote and } \\
\text { Culturally Distinct } \\
\text { Populations }\end{array}$ & $\begin{array}{l}\text { Deliver treatment services in innovative ways to hard-to- } \\
\text { reach populations and to serve as a model program to } \\
\text { be replicated for Alaskan Natives, Native Americans, and } \\
\text { Native Hawaiians. }\end{array}$ & 3 & $1,765,000$ & 3 & $2,018,782$ \\
\hline $\begin{array}{l}\text { Farm Resource } \\
\text { Center }\end{array}$ & $\begin{array}{l}\text { Supplemental funding to the Center for Mental Health } \\
\text { Services to continue and augment mental health and } \\
\text { substance abuse treatment services and enhance } \\
\text { outreach to rural, coal mining, and farm populations in } \\
\text { West Virginia and Illinois, especially to those who are } \\
\text { poor, disabled, or elderly and to child-bearing women. }\end{array}$ & $\mathrm{a}$ & a & 1 & 50,000 \\
\hline Marijuana-Adults & $\begin{array}{l}\text { Examine the efficacy of brief treatment interventions for } \\
\text { marijuana dependence and whether these treatments } \\
\text { are effective in diverse populations with a higher } \\
\text { proportion of minority representation. }\end{array}$ & 4 & $1,288,805$ & 4 & $1,844,311$ \\
\hline $\begin{array}{l}\text { Marijuana- } \\
\text { Adolescents }\end{array}$ & $\begin{array}{l}\text { Examine the effectiveness of treatment for marijuana- } \\
\text { dependent youth, comparing five promising approaches } \\
\text { that vary in orientation, duration, mode of delivery, and } \\
\text { cost. }\end{array}$ & a & a & 5 & $3,219,164$ \\
\hline $\begin{array}{l}\text { Methamphetamine } \\
\text { Treatment }\end{array}$ & $\begin{array}{l}\text { Test the replicability of specific nonresidential programs } \\
\text { for the treatment of methamphetamine abuse and their } \\
\text { cost-effectiveness. }\end{array}$ & a & a & 8 & $3,024,100$ \\
\hline
\end{tabular}


Appendix III

KDA Grant Programs and F unding for Drug

Abuse Treatment

\begin{tabular}{|c|c|c|c|c|c|}
\hline \multirow[b]{2}{*}{ Program } & \multirow[b]{2}{*}{ Description } & \multicolumn{2}{|c|}{ Fiscal year 1996} & \multicolumn{2}{|c|}{ Fiscal year 1998} \\
\hline & & Grantees & Funding & Grantees & Funding \\
\hline $\begin{array}{l}\text { Homelessness } \\
\text { Prevention }\end{array}$ & $\begin{array}{l}\text { Document homelessness prevention models for } \\
\text { individuals with serious mental illness and substance } \\
\text { abuse disorders who are homeless, formerly homeless, } \\
\text { or at risk for homelessness and who have had contact } \\
\text { with the mental health or substance abuse treatment } \\
\text { system. }\end{array}$ & 12 & $1,040,695$ & 8 & $1,826,921$ \\
\hline Disaster Assistance & $\begin{array}{l}\text { Provide expanded substance abuse treatment services } \\
\text { during a natural disaster. }\end{array}$ & 1 & 663,708 & a & \\
\hline Campus & $\begin{array}{l}\text { Develop a model comprehensive program for the } \\
\text { treatment of substance abuse in the national capital } \\
\text { area. }\end{array}$ & 1 & 600,000 & a & \\
\hline Minority Fellowship & $\begin{array}{l}\text { Provide doctoral-level training to increase the number of } \\
\text { professionals qualified to develop and implement } \\
\text { services for underserved ethnic populations with mental } \\
\text { health and substance abuse problems. }\end{array}$ & a & a & 4 & 340,000 \\
\hline $\begin{array}{l}\text { Exemplary } \\
\text { Programs- } \\
\text { Adolescents }\end{array}$ & $\begin{array}{l}\text { Identify those regimens for treating adolescent heroin } \\
\text { abusers that appear to be exemplary and may be useful } \\
\text { for further replication and dissemination. }\end{array}$ & a & a & 5 & $2,116,079$ \\
\hline $\begin{array}{l}\text { Community Action } \\
\text { Grants }\end{array}$ & $\begin{array}{l}\text { Support the adoption of exemplary practices for Hispanic } \\
\text { adults and adolescents with mental health or substance } \\
\text { abuse problems. }\end{array}$ & a & a & 3 & 442,944 \\
\hline Conference Grant & $\begin{array}{l}\text { Support domestic conferences for knowledge synthesis } \\
\text { and dissemination. }\end{array}$ & a & a & 7 & 309,066 \\
\hline Total & & 111 & $\$ 78,160,112$ & 210 & $\$ 98,418,167$ \\
\hline
\end{tabular}

aprogram not funded. 


\section{State Program Assessments}

\begin{tabular}{|c|c|c|c|}
\hline State and program & $\begin{array}{l}\text { Client } \\
\text { populations }\end{array}$ & $\begin{array}{l}\text { Treatment } \\
\text { services }\end{array}$ & Selected outcome measures and results \\
\hline \multicolumn{4}{|l|}{ California } \\
\hline $\begin{array}{l}\text { California Drug and Alcohol } \\
\text { Treatment Assessment }\end{array}$ & All clients & All services & $\begin{array}{l}\text { - Drug use declined by } 40 \text { percent. } \\
\text { - Employment results not conclusive. } \\
\text { - Hospital admissions reduced by } 33 \text { percent. } \\
\text { - Criminal activity declined by } 66 \text { percent. }\end{array}$ \\
\hline \multicolumn{4}{|l|}{ Florida } \\
\hline $\begin{array}{l}\text { Ongoing performance } \\
\text { measurement system }\end{array}$ & All clients & All services & $\begin{array}{l}\text { - Abstinence for } 65 \text { percent of children and } 61 \text { percent of } \\
\text { adults. } \\
\text { - Employment achieved by } 63.4 \text { percent. }\end{array}$ \\
\hline $\begin{array}{l}\text { Evaluation of Substance Abuse } \\
\text { Treatment Outcomes }\end{array}$ & Adults & $\begin{array}{l}\text { Residential, } \\
\text { outpatient }\end{array}$ & $\begin{array}{l}\text { - } 11 \text { percent of clients completing treatment who were drug } \\
\text { free at discharge reported a substance abuse problem, } \\
\text { compared to } 26 \text { percent of clients who did not complete } \\
\text { treatment. } \\
\text { - } 70 \text { percent of clients who completed treatment were } \\
\text { employed, compared to } 58 \text { percent of clients who did not } \\
\text { complete treatment. }\end{array}$ \\
\hline
\end{tabular}

\section{North Carolina}

Ongoing performance

measurement system
All clients

management

- Declines in drug use improved significantly.

- Abstinence improved significantly.

- Employment modestly improved.

- Mental health moderately improved.

- Living arrangement modestly improved.

TOPPS

All clients

Outpatient

- Drug use declined substantially for each type of substance.

- Medical overnight stays reduced by 4 percent, and emergency room visits reduced by 18 percent.

- Psychiatric overnight stays reduced by 16 percent.

Perinatal and Maternal Substance Abuse Treatment Initiative

Pregnant and postpartum women and adolescents

Treatment Alternatives to Street Criminal justice Crime (TASC)

Methadone Treatment Quality Narcotic addicted Methadone Assurance System

\section{Prenatal treatment \\ - 73 percent of clients had full-term births; 13 percent of births} born at very low birth weight.

All services $\quad$ Abstinence occurred for 48 percent at discharge.

- Drug use for those still using drugs was less often.

- 82 percent had no arrests while in the program.

- Abstinence from injected drug use for 94 percent.

- Drug use urine screens for opiates negative for 79 percent; for cocaine, 88 percent.

- Employment full-time for 54 percent.

- No medical overnight stays for 93 percent, and no emergency room visits for 82 percent.

- No arrests in the past 12 months for 95 percent. 


\begin{tabular}{|c|c|c|c|}
\hline State and program & $\begin{array}{l}\text { Client } \\
\text { populations }\end{array}$ & $\begin{array}{l}\text { Treatment } \\
\text { services }\end{array}$ & Selected outcome measures and results \\
\hline \multicolumn{4}{|l|}{ Ohio } \\
\hline TASC & $\begin{array}{l}\text { Court-referred } \\
\text { juveniles }\end{array}$ & All treatment & $\begin{array}{l}\text { - Abstinence occurred for } 76 \text { percent of discharges. } \\
\text { - Drug use testing negative for } 92 \text { percent. } \\
\text { - Rearrest rate: } 7 \text { percent. }\end{array}$ \\
\hline TASC & $\begin{array}{l}\text { Court-referred } \\
\text { adults }\end{array}$ & All treatment & $\begin{array}{l}\text { - Abstinence occurred for } 47 \text { percent of discharges. } \\
\text { - Drug use urine testing negative for } 88 \text { percent; for breath } \\
\text { testing, } 91 \text { percent. } \\
\text { - Employment obtained and improved for } 1,017 \text { clients, or } 46 \\
\text { percent of discharges. } \\
\text { - Living arrangement stable for } 1,132 \text {, or } 51 \text { percent of } \\
\text { discharges }\end{array}$ \\
\hline Analysis of Adult TASC & $\begin{array}{l}\text { Court-referred } \\
\text { adults }\end{array}$ & $\begin{array}{l}\text { Counseling, } \\
\text { urinalysis }\end{array}$ & $\begin{array}{l}\text { - Criminal activity significantly lower for clients completing the } \\
\text { program. }\end{array}$ \\
\hline $\begin{array}{l}\text { Arrest and Reincarceration } \\
\text { Following Prison Release }\end{array}$ & Adult male felons & $\begin{array}{l}\text { Therapeutic } \\
\text { community }\end{array}$ & - Rearrests were slightly reduced among participants. \\
\hline $\begin{array}{l}\text { Tapestry Therapeutic } \\
\text { Community; Our Awareness of } \\
\text { Self Increases Success } \\
\text { Therapeutic Community }\end{array}$ & $\begin{array}{l}\text { Female and male } \\
\text { incarcerated } \\
\text { felons }\end{array}$ & $\begin{array}{l}\text { Residential, other } \\
\text { drug abuse } \\
\text { treatment }\end{array}$ & - Women had lower rearrests; males, no difference. \\
\hline \multicolumn{4}{|l|}{ Texas } \\
\hline Treatment Research Institute & Adults & $\begin{array}{l}\text { Residential, } \\
\text { outpatient }\end{array}$ & $\begin{array}{l}\text { - Abstinence achieved by } 56 \text { to } 61 \text { percent for alcohol and } \\
\text { other drugs. } \\
\text { - Employment achieved by } 51 \text { to } 64 \text { percent. }\end{array}$ \\
\hline $\begin{array}{l}\text { Treatment Alternatives to } \\
\text { Incarceration Program }\end{array}$ & Adult criminals & Outpatient & - Criminal activity decreased the longer the stay in treatment. \\
\hline $\begin{array}{l}\text { Statewide Treatment Outcome } \\
\text { Data }\end{array}$ & Adults & $\begin{array}{l}\text { Detoxification, } \\
\text { residential, } \\
\text { outpatient, } \\
\text { methadone }\end{array}$ & $\begin{array}{l}\text { - Abstinence occurred for } 72 \text { percent of clients. } \\
\text { - Drug use reduced for } 64 \text { percent. } \\
\text { - Employment gained by } 33 \text { percent. } \\
\text { - Arrest rate at followup was } 5 \text { percent. }\end{array}$ \\
\hline \multicolumn{4}{|l|}{ Washington } \\
\hline $\begin{array}{l}\text { Cost Savings in Medicaid } \\
\text { Medical Expenses }\end{array}$ & Indigents & $\begin{array}{l}\text { Intensive inpatient, } \\
\text { outpatient }\end{array}$ & $\begin{array}{l}\text { - Physical health costs } \$ 4,500 \text { less than for untreated clients } \\
\text { over 5-year period. }\end{array}$ \\
\hline $\begin{array}{l}\text { Alcoholism and Drug Addiction } \\
\text { Treatment and Support Act } \\
\text { (ADATSA): Economic Benefits } \\
\text { and Costs }\end{array}$ & Indigents & $\begin{array}{l}\text { Intensive inpatient, } \\
\text { outpatient, } \\
\text { residential }\end{array}$ & $\begin{array}{l}\text { - Employment earnings more than double that of untreated } \\
\text { clients. } \\
\text { - Physical health costs decreased by nearly } 50 \text { percent for } \\
\text { treated clients. }\end{array}$ \\
\hline $\begin{array}{l}\text { ADATSA Treatment Outcomes: } \\
\text { Employment and Cost } \\
\text { Avoidance }\end{array}$ & Indigents & $\begin{array}{l}\text { Intensive inpatient, } \\
\text { outpatient, } \\
\text { vocational training }\end{array}$ & $\begin{array}{l}\text { - Employment earnings for those who completed training } \\
\text { nearly doubled. } \\
\text { - Physical health costs were less than half that of nontreated } \\
\text { clients. }\end{array}$ \\
\hline $\begin{array}{l}\text { Employment Outcomes of } \\
\text { Indigent Clients Receiving } \\
\text { Alcohol and Drug Treatment }\end{array}$ & Indigents & $\begin{array}{l}\text { Intensive inpatient, } \\
\text { outpatient, } \\
\text { recovery house }\end{array}$ & $\begin{array}{l}\text { - Employment earnings increased on average by } \$ 1.30 \text { for } \\
\text { every day of inpatient care received. }\end{array}$ \\
\hline
\end{tabular}




\begin{tabular}{|c|c|c|c|}
\hline State and program & $\begin{array}{l}\text { Client } \\
\text { populations }\end{array}$ & $\begin{array}{l}\text { Treatment } \\
\text { services }\end{array}$ & Selected outcome measures and results \\
\hline $\begin{array}{l}\text { Employment Outcomes of } \\
\text { Chemical Dependency } \\
\text { Treatment and Additional } \\
\text { Vocational Services }\end{array}$ & Indigent & $\begin{array}{l}\text { Intensive inpatient, } \\
\text { outpatient, } \\
\text { vocational training }\end{array}$ & $\begin{array}{l}\text { - Employment earnings were higher for } 46 \text { percent of clients } \\
\text { who completed vocational services. }\end{array}$ \\
\hline $\begin{array}{l}\text { Substance Abuse, Treatment, } \\
\text { and Birth Outcomes for } \\
\text { Pregnant and Postpartum } \\
\text { Women }\end{array}$ & $\begin{array}{l}\text { Pregnant and } \\
\text { postpartum } \\
\text { women }\end{array}$ & $\begin{array}{l}\text { Prenatal treatment, } \\
\text { prenatal and } \\
\text { postpartum } \\
\text { diagnosis, } \\
\text { Medicaid }\end{array}$ & $\begin{array}{l}\text { - Overall rate of low birth weights for infants whose mothers } \\
\text { were treated was lowered by } 2.9 \text { percent. }\end{array}$ \\
\hline $\begin{array}{l}\text { Evaluation of Pioneer Center } \\
\text { North }\end{array}$ & $\begin{array}{l}\text { Mentally ill, } \\
\text { chemically } \\
\text { addicted, and } \\
\text { involuntary } \\
\text { chemical } \\
\text { dependency } \\
\text { treatment }\end{array}$ & $\begin{array}{l}\text { Residential } \\
\text { (nonhospital) }\end{array}$ & $\begin{array}{l}\text { - Mental health services declined after treatment } 7 \text { to } 25 \\
\text { percent. } \\
\text { - Physical health costs decreased between } \$ 2.2 \text { million and } \\
\$ 1.1 \text { million for those who received treatment. }\end{array}$ \\
\hline $\begin{array}{l}\text { Division of Alcohol and } \\
\text { Substance Abuse One-year } \\
\text { Adolescent Outcomes Report }\end{array}$ & Adolescents & $\begin{array}{l}\text { Intensive inpatient } \\
\text { (nonhospital), } \\
\text { outpatient }\end{array}$ & $\begin{array}{l}\text { - Abstinence achieved for } 6 \text { months on average by about } 40 \\
\text { percent of clients. } \\
\text { - Number of drug substances used dropped by about } 3 \text {. } \\
\text { - Mental health problems decreased from } 42 \text { percent to } 29 \\
\text { percent in psychiatric symptoms. } \\
\text { - Physical health problems decreased from } 17 \text { percent to } 11 \\
\text { percent in medical hospitalization and } 42 \text { percent to } 28 \\
\text { percent in emergency room visits. } \\
\text { - Criminal activity decreased in arrest for misdemeanors by } 25 \\
\text { percent, felonies by } 23 \text { percent, and drug violations by } 24 \\
\text { percent. }\end{array}$ \\
\hline $\begin{array}{l}\text { Division of Alcohol and } \\
\text { Substance Abuse 18-Month } \\
\text { Adolescent Outcomes Report }\end{array}$ & Adolescents & $\begin{array}{l}\text { Intensive inpatient } \\
\text { (nonhospital), } \\
\text { outpatient }\end{array}$ & $\begin{array}{l}\text { - Abstinence was achieved for } 6 \text { months on average by about } \\
45 \text { percent of the clients. } \\
\text { - Employment absenteeism or tardiness dropped by } 33 \\
\text { percent. } \\
\text { - Mental health problems decreased by } 17 \text { percent in major } \\
\text { depressive syndromes and by } 14 \text { percent in suicide } \\
\text { attempts. } \\
\text { - Physical health problems decreased in emergency room } \\
\text { visits. } \\
\text { - Criminal activity decreased in drug dealing, theft, and } \\
\text { prostitution by } 48 \text { percent. }\end{array}$ \\
\hline $\begin{array}{l}\text { Treatment Outcome Evaluation: } \\
\text { Youth Admitted to Residential } \\
\text { Chemical Dependency } \\
\text { Treatment Under the Provisions } \\
\text { of the "Becca" Bill }\end{array}$ & Youth & $\begin{array}{l}\text { Intensive inpatient } \\
\text { (nonhospital) }\end{array}$ & $\begin{array}{l}\text { - Abstinence was achieved for } 40 \text { percent } 3 \text { months after } \\
\text { treatment. } \\
\text { - Drug use prevalence decreased by } 46 \text { percent for } \\
\text { marijuana. } \\
\text { - Criminal activity decreased in selling drugs by } 51 \text { percent, } \\
\text { breaking and entering by } 39 \text { percent. }\end{array}$ \\
\hline $\begin{array}{l}\text { Adolescent Treatment Outcome } \\
\text { Study Report }\end{array}$ & Adolescents & $\begin{array}{l}\text { Intensive inpatient } \\
\text { (nonhospital) }\end{array}$ & $\begin{array}{l}\text { - Abstinence occurred for two-thirds of the sample at } 6 \\
\text { months. } \\
\text { - Criminal activity decreased fourfold for felony arrests after } 1 \\
\text { year. }\end{array}$ \\
\hline
\end{tabular}


Appendix IV

State Program Assessments

\begin{tabular}{|c|c|c|c|}
\hline State and program & $\begin{array}{l}\text { Client } \\
\text { populations }\end{array}$ & $\begin{array}{l}\text { Treatment } \\
\text { services }\end{array}$ & Selected outcome measures and results \\
\hline $\begin{array}{l}\text { Adolescent Treatment Outcome } \\
\text { Study Report: Six-Month } \\
\text { Follow-up of Clients Referred by } \\
\text { the Juvenile Justice System, } \\
\text { Those Served by Schools, as } \\
\text { Well as Those Whose Parents } \\
\text { Currently Abuse Substances }\end{array}$ & $\begin{array}{l}\text { Adolescents } \\
\text { referred by court } \\
\text { or juvenile justice } \\
\text { system }\end{array}$ & $\begin{array}{l}\text { Intensive inpatient } \\
\text { (nonhospital) }\end{array}$ & $\begin{array}{l}\text { - Abstinence occurred for } 5 \text { percent more court-referred } \\
\text { clients than others. } \\
\text { - Criminal activity decreased significantly for abstinent clients } \\
\text { compared to relapsed clients. }\end{array}$ \\
\hline
\end{tabular}

Continued from Previous Page 
The first copy of each GAO report is free. Additional copies of reports are $\$ 2$ each. A check or money order should be made out to the Superintendent of Documents. VISA and MasterC ard credit cards are accepted, also.

Orders for 100 or more copies to be mailed to a single address are discounted 25 percent.

Orders by mail:

U.S. General Accounting Office

P.O. B ox 37050

Washington, DC 20013

Orders by visiting:

Room 1100

700 4th St. NW (corner of 4th and G Sts. NW)

U.S. General Accounting Office

Washington, DC

Orders by phone:

(202) 512-6000

fax: (202) 512-6061

TDD ( 202) 512-2537

E ach day, GAO issues a list of newly available reports and testimony. To receive facsimile copies of the daily list or any list from the past 30 days, please call (202) 512-6000 using a touchtone phone. A recorded menu will provide information on how to obtain these lists.

Orders by Internet:

For information on how to access GAO reports on the Internet, send an e-mail message with "info" in the body to:

info@www.gao.gov

or visit GAO's World Wide Web home page at:

http://www.gao.gov

To Report Fraud, Waste, or Abuse in Federal Programs

\section{Contact one:}

- Web site: http://www.gao.gov/fraudnet/fraudnet.htm

- e-mail: fraudnet@gao.gov

- 1-800-424-5454 (automated answering system) 

United States

General Accounting Office

Washington, D.C. 20548-0001

Official Business

Penalty for Private Use $\$ \mathbf{3 0 0}$

Address Correction Requested
Bulk Rate

Postage \& F ees Paid GAO

Permit No. GI00

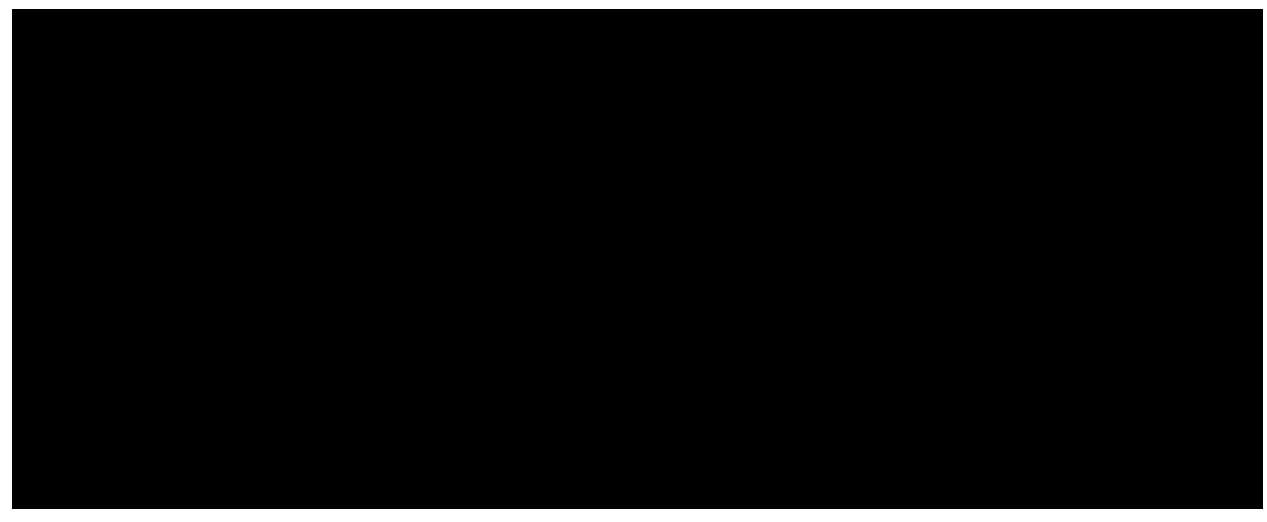

